\title{
Biotechnology

\section{Regulated promoters applied to plant engineering: an insight over promising soybean promoters under biotic stress and their cis-elements}

\author{
Bruno Paes de Melo a,b,*\#, Stéfanie Menezes de Mouraa,b\#, Carolina Vianna Morgante ${ }^{a, c}$, \\ Daniele Heloisa Pinheiro ${ }^{a}$, Nayara Sabrina Freitas Alves ${ }^{a, d}$, Paolo Lucas Rodrigues-Silva ${ }^{a, e}$, \\ Isabela Tristan Lourenço-Tessuttia,b, Rosângela Vieira Andrade ${ }^{\mathrm{b}, \mathrm{e}}$, \\ Rodrigo Rocha Fragoso ${ }^{a, f}$, Maria Fatima Grossi-de-Sa,b,e*
}

\author{
${ }^{a}$ Embrapa Genetic Resources and Biotechnology, Brasília, DF, Brazil \\ ${ }^{b}$ National Institute of Science and Technology - INCT Plant Stress Biotech, Brasília, DF, Brazil \\ 'Embrapa Semiarid, Petrolina, PE, Brazil \\ ${ }^{d}$ Federal University of Paraná, Biotechnology and Bioprocess Engineering Program, Curitiba, PR, Brazil \\ eCatholic University of Brasília, Genomic Sciences and Biotechnology Program, Brasília, DF, Brazil \\ ${ }^{f}$ Embrapa Savannah, Planaltina, DF, Brazil
}

\begin{abstract}
Highlights
- Although the significant number of reports on plants carrying transgenes conferring specific characteristics, little is known about plant-specific promoters, mainly those that are agronomically relevant, such as cotton and soybean. This review highlights promising plant promoters applied to molecular breeding and conserved cis-acting elements from promoters responsive to different biotic stresses in soybean, raising new possibilities for constructing synthetic and optimized promoters.
\end{abstract}

Received 03 August, 2021; Revised 27 September, 2021; Accepted 08 October, 2021.

\#These authors contributed equally to this work.

\section{KEYWORDS}

Soybean promoters;

Transcription

regulation;

Plant promoters;

Stress-inducible

genes;

Plant genetic

engineering.

\begin{abstract}
Promoters are upstream gene regulatory sequences recognized by transcription factors (TFs) involved in controlling transcription initiation and progression. For modern crop improvement, the design of efficient gene constructs relies on promoter efficiency, tissue specificity, and other characteristics that allow the introgression of agronomically relevant traits to overcome biotic and abiotic stresses. Several constitutive viral promoters, such as pCaMV35S, remain widely employed in the transgenic plant generation, but their indiscriminate use leads to gene silencing triggering and metabolic penalties impacting plant fitness. The identification and functional characterization of plant-derived promoters can unveil alternatives to commonly used non-homologous promoters; however, knowledge over them remains limited, especially for crops. This review summarizes plant promoters used to drive foreign gene expression in homologous and heterologous systems, focusing on inducible soybean promoters from genes upregulated by different biotic stresses. Analyses of these soybean promoters revealed 22 coincident cis-acting elements that can be used for synthetic engineering promoters responsive to multiple biotic stresses and, therefore, efficiently drive gene expression, conferring desirable traits in transgenic soybean. In addition, we also revisited commercial and protected promoters to provide an update on soybean promoters and gain new insights into superior crops' development.
\end{abstract}

\footnotetext{
*Corresponding author.

E-mail: brunopaesdemelo@gmail.com (B. P. Melo);

fatima.grossi@embrapa.br (M. F. Grossi-de-Sa).
}

2452-0721/2452-0721 @ 2021 Sociedade Brasileira de Biotecnologia. This is an Open Access article distributed under the terms of the Creative Commons Attribution-Noncommercial No Derivative License, which permits unrestricted non-commercial use, distribution, and reproduction in any medium provided the original work is properly cited and the work is not changed in any 


\section{Graphical abstract}

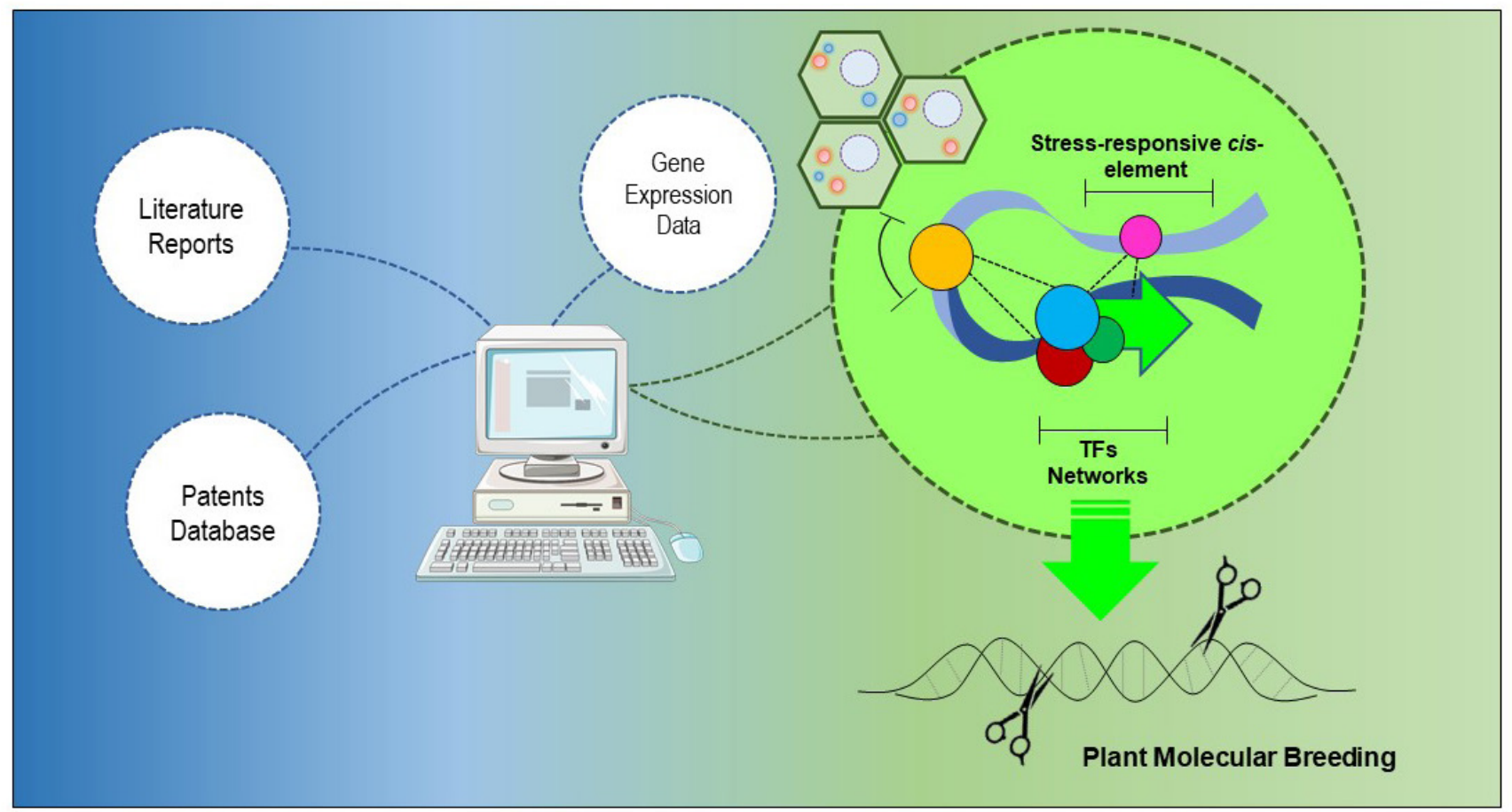

\section{Introduction}

New approaches in biotechnology have allowed considerable progress in the introduction of beneficial traits to improve crops for higher production under normal and stressful conditions. Despite several transcriptional and translational mechanisms in the control of gene expression because of posterior processes (e.g., splicing, RNA/protein transport, gene silencing, ubiquitination), those involving promoterdriven gene transcription are the most important in plants. This strategy is advantageous when the goal is to incorporate new traits into crops by driving transgene expression (Hernandez-Garcia \& Finer, 2014).

Theoretically, promoters are regulatory regions upstream of genes that grant specific transcription rates. They can be classified according to the position of the regulatory sequences relative to the transcription starting site (TSS): core promoters include minimal cis-elements, such as TATA and GACA boxes (located at -10 and - 35 bp of the TSS, respectively), required for basal transcription in eukaryotic cells. They are widely distributed, and the assembly of pre-initiation of transcription pre-initiation of transcription complex (PIC) complex derives from them (Louder et al., 2016). Proximal promoters are typically located within 1,000 bp upstream of the TSS and encompass key specific regulatory sequences recognized by specific TFs in a cell fate-dependent manner. Finally, distal promoters comprise long-distance regulatory sequences whose chromatin topology imposes physical interactions with the basal transcription machinery, either favorable or unfavorable, enhancing or suppressing gene transcription, depending on the nature of their cis-elements.

Transcription regulation is determined by the interaction of several enhancers or silencers in the DNA sequence and specialized proteins, designated transcription factors (TFs), which recognize conserved cis-elements and interact simultaneously with the basic transcriptional machinery. Since TFs can be dynamically present or absent in cells, depending on life stage, cell type, physiological conditions and hormone signals, biotic- and abiotic-stresses, transcriptional regulation of gene expression is finely-tuned regulated, resulting in appropriated transcription rates in consonance with all sorts of internal and environmental signals (Melo et al., 2021).

Overall, genes can be classified into two main categories, based on their expression profile: i. constitutive genes (also referred to as housekeeping genes), whose expression is nearly constant across tissues/organs at all developmental stages and under all environmental conditions; or ii. regulated genes, whose expression can increase a thousand-fold in response to specific stimuli. They can also be classified as spatiotemporally regulated (tissue or lifespan specific) or induced promoters (hormone-, abiotic stress-, wounding-, pathogen-inducible expression). Their common characteristic is that they are uniquely transcribed by RNA polymerase II (RNA pol II). So naturally, the promoters of these genes harbor sites for RNA pol II and are collectively designated pol II promoters (Bitas et al., 2016; Kummari et al., 2020).

A compelling and universal correlation suggests that constitutive genes are generally driven by CPG promoters (previously referred to as TATA-less), whereas most regulated genes are strongly controlled by TATA-containing promoters (Müller \& Tora, 2014). In plants, a comprehensive analysis of thousands of core promoter sequences showed a high incidence of AT base pairs, with particularly strong AT enrichment around -30 bp, suggesting that TATA-like promoters are present in $31 \%$ of plant promoters (Hetzel et al., 2016). TATA-like promoters confer highly regulated gene expression, with initiation concentrated at the TSS and nearby regulatory 
sites, including canonical CAT-boxes and Inr sequences, in addition to the downstream 5'UTR. Some genes exhibit TSS variants, typically in response to tissue differentiation, physiological regulation, and genetic variability (Hetzel et al., 2016), which impose additional levels of transcriptional regulation. A comprehensive mapping of Arabidopsis nascent RNA found "TYA(+1)YYN" and "TYA(+1)GGG" as a consensus Inr (Hetzel et al., 2016) that could be predicted using several algorithms. For CAT-boxes, 5'(T/C)(A/G)(A/G) $\operatorname{CCAATC}(\mathrm{A} / \mathrm{G}) 3^{\prime}$ is considered the consensus sequence and can recruit NFY, which enhances gene activation across TFs through nucleosome replacement (Vernimmen \& Bickmore, 2015). Unlike GC-boxes, the CAT box is position-dependent, typically occurring around -60 to -100 . TATA-containing genes are generally not involved in essential cellular functions (Bae et al., 2015). Similarly, CAAT boxes are rarely found in constitutively expressed genes in all cell types (Tripathi et al., 2010).

Briefly, CpG promoters display GC-rich regions with several CpG sites (Saxonov et al., 2006), i.e., cytosine bound to guanosine $5^{\prime}$ phosphate, where cytosine may or may not be methylated as an epigenetic mark. When unmethylated, CpG islands (typically exhibiting dispersed SCTs of 50-100 bp) are recognized by TFs that recruit RNA pol II for transcription initiation. In plants, methylation patterns of $\mathrm{CpG}$ islands are strikingly uniform, negatively correlating with constitutive expression of housekeeping genes (Song et al., 2013). Another feature of CPG promoters is the presence of additional regulatory core sequences, such as GC-box (KRGGCGKRRY, usually GGGCGG motif - about -40 to -100) and DRE and TCT motifs (Lorberbaum \& Barolo, 2015). DRE motifs are predictable TATCGATA sequences in proximal promoters (-200 bp). They positively regulate transcription in different ways, depending on the enhancer function (Lorberbaum \& Barolo, 2015), but at different rates with fluctuation up to 50 -fold, likely associated with the number of GC-box and proximal enhancers.

Besides the cis-elements of the core promoter, the combination of different regulatory sequences recognized by TFs delineates the induction pattern of a gene and, therefore, the promoter's responsiveness. The ACGT core motif, found in G-boxes, C-boxes, A-boxes, and ABRE (ABA binding responsive element), is recognized by bZIPs in many promoters. To date, plant genomes encompass dozens of bZIPs in different species [(75 in Arabidopsis thaliana, 89 in rice, 125 in maize, 131 in soybean, and 69 in tomato (Fassler et al., 2002; Wei et al., 2012; Llorca et al., 2014; Li et al., 2015; Wang et al., 2015)]. The bZIPs are frequently linked to the control of normal plant morphophysiology and specific responses to biotic and abiotic stresses. Similarly, W-box is the WRKY-recognized cis-element (consensus: C/TTGACC/T) detected in several gene promoters responsive to multiple developmental stresses and processes, such as senescence (Basu et al., 2014; Llorca et al., 2014; Sheshadri et al., 2016). Along these lines, some TF families integrate hormonal signaling and physiological remodeling. The cis-elements recognized by these TFs are valuable sources of multipleresponse regulatory sequences for promoter engineering.

AP2/ERF TFs control processes of floral development, seed germination, and yield regulation. Considering the common hormonal branch of these processes and responses to multiple stresses, mainly coordinated by salicylic acid (SA), jasmonic acid (JA), ethylene (ETH), and abscisic acid (ABA), AP2/ERF TFs also respond to environmental signals (Cui et al., 2016; Gu et al., 2017) by recognizing the A/ GCCGAC motif in DRE (Basu et al., 2014) and ERFb (Yamada \& Sato 2013), and CAACA in RAVb elements (Feng et al., 2014; Moran Lauter et al., 2014). The same is reported for NAC TFs, which recognize NACr elements (ACACGCATGT) (Yamaguchi-Shinozaki \& Shinozaki 2005).

Therefore, studies of gene function and global variation in gene expression provide the most abundant reliable information on inducible promoters. From this, useful features on expression kinetics, specific induction or repression profile, and time or tissue dependence can be obtained, which allow retrieving useful promoters for a predictable increase in gene expression, in a specific tissue, under specific conditions, with minimal penalties on plant yield (Porto et al., 2014; Bitas et al., 2016; Kummari et al., 2020). The variety of TFs, the different cis-elements they recognize, and the plasticity of the DNA-binding domain in interacting with secondary regulatory sequences (partially divergent from canonical cis-elements) make promoters' engineering a promising and enthusing research field in synthetic biology and molecular breeding. Furthermore, the application and use of synthetic promoters have expanded the concern for regulating the expression of different genes of interest in response to pathogen attack or other specific stimuli (Koschmann et al., 2012).

Herein, we have attempted to summarize the progress in the elucidation and functional characterization of plantspecific promoter sequences, primarily regulated promoters, whose impact of conserved cis-elements associated with response to multiple stimuli can provide a useful tool for crop engineering. Our analysis focused on soybean genes highly responsive to several biotic stresses and uncovered 22 coincidental cis-acting elements of 50 genes upregulated by viruses, fungi, insects, and nematodes. We also reexamined commercial and patent-protected plant promoters, which revealed that constitutive and regulated promoters have been continuously patented; however, constitutive promoters are five times more characterized and protected annually $(213.36 \pm 108.84)$ than regulated ones $(46.45 \pm 21.89)$. Overall, all data provide an updated dataset for projecting transgene expression in plants and designing synthetic promoters in soybean, setting new trends in the field in modern agribusiness.

\section{Constitutive plant promoters}

Constitutive promoter encompasses transcriptional regulatory regions widely expressed in plant tissues and organs, not regulated by specific conditions or specific transcription factors, universally applied in transgene expression in plants (Jiang et al., 2018; Ali \& Kim, 2019; Kummari et al., 2020).

Viral promoters, such as cauliflower mosaic virus (pCaMV35S), peanut chlorotic streak virus ( $p$ PC1SV), and figwort mosaic virus ( $p F M V)$ promoters have been used in plant transformation over the years and are the most widely 
used constitutive promoters in plant engineering. However, in most cases, plant constitutive promoters might be a more suitable option for plant transformation due to their plant origin. Additionally, plant transcriptional regulatory regions harbor cis-acting elements compatible with basal and plant cell-specific transcription factors, allowing precise regulation of gene expression compatible with their regulatory machinery (Mittler \& Blumwald 2010; Bitas et al., 2016).

Despite its strong quasi-universal gene expression capacity, $p C a M V 35 S$ has become the most widely used constitutive viral promoter in transgenic plants. However, its activity is generally low in reproductive tissues, prompting a demand for plant tissue-specific promoters towards the expression of genes whose phenotypical effect is relevant in flower buds, anthers, pollen, and related tissues (Moura et al., 2021). In addition, excessively high transcript levels generated under viral promoter's control can interplay some pleiotropic effects on transgenic plants (Freitas et al., 2019). For example, higher transcriptional ratio is frequently associated with protein accumulation and, primarily in non-target plant tissues, might be energy costly for the plant. Furthermore, simultaneous expression of different transgenes under the control of the same promoter usually triggers post-transcriptional gene silencing mechanisms (Freitas et al., 2019).

Plant constitutive promoters have emerged as a viable solution to these limitations (Porto et al., 2014). These promoters can be specifically applied to regulate plant resistance for pathogen or herbicide-related genes, thus improving plant performance under diverse conditions. Constitutive plant promoters can drive gene expression in most tissues and organs at different stages of development (Bhattacharyya et al., 2012; Jiang et al., 2018). Nonetheless, they can be a strategy for priming the defense of transgenic plants against abiotic or biotic stresses, as the target protein will be continuously produced (Singhal et al., 2016; Kummari et al., 2020).

Another feature to be addressed over plant constitutive promoters relies on the evidence that constitutive promoters of monocots and eudicots are usually more efficient in homologous systems (Wilmink et al., 1995). The most commonly used constitutive promoters in monocot crops are the rice Actin1 (pOsAct1) (McElroy et al., 1990, 1991), the maize Ubiquitin 1 and 2 (pZmUbi 1 and pZmUbi2) (Christensen et al., 1992), and Alcohol Dehydrogenase 1 (pZmAdh1) (Kyozuka et al., 1991). As summarized in Table 1, several monocot promoters have been identified and evaluated for application in plant transformation as alternatives to viral options.

The rice pOsActin 1 was used to drive the Bacillus thuringiensis Cry1A(b) gene expression in indica and japonica rice-varieties, leading to $\mathrm{Cry} 1 \mathrm{~A}(\mathrm{~b})$ protein levels similar to those driven by $p C a M V 35 S$. Efficient expression of the gene ensured plant protection against yellow stem borer (Scirpophaga incertulas) larvae (Datta et al., 1998).

Other monocot-specific promoters have also been applied to control insects, fungi, viruses, and nematodes. The ubiquitin extension protein ( $p$ Uep1) promoter from the oil palm tree could drive B-glucuronidase expression (uidA; GUS) transiently in different plant tissues, including embryogenic calli, embryoid, immature embryo, young leaf, green leaf, mesocarp, and meristematic tissues (Masura et al., 2010). Interestingly, it has also reported the potential for use in dicot systems, displaying transcriptional regulatory activity in tobacco (Masura et al., 2010). The pAPX, pPGD1, and pR1G1B from rice were also investigated using GFP as a reporter gene in the homologous system. All promoters were highly active in the whole plant at vegetative and reproductive stages, and the pPGD1 showed excellent transcriptional activity as similarly observed for the well-characterized pZmUbi-1 (Park et al., 2012). The same approach was applied to analyze the pOsUbi1 promoter driving GUS gene expression in native plants compared to pZmUbi1 and rice Gibberellic Acid Insensitive ( $p G A l$ ) promoters. The expression levels were higher when pOsUbi1 was employed, followed by pZmUbi 1 and pGAl, standing pOsUbi 1 as a promising promoter for synthetic biology, capable of driving constitutive gene expression in rice (Bhattacharyya et al., 2012), as has also been shown for pOsCon1 (Li et al., 2014).

Expressive progress on promoters' characterization in monocots has been made, but it remains limited to certain species, such as rice ( $O$. sativa) and corn (Z. mays). Few precedents in the literature report characterization of promoters in other important monocot crops, such as wheat (Trictum ssp.), sugarcane (Sacharum ssp.), barley (Hordeum vulgare), and several others, limiting the expression of transgenes in these plant systems under the control of endogenous promoters. Eudicot characterized promoters are distributed in a slightly wider variety of plants (Table 2); however, most precedents describe promoters from Arabidopsis and tobacco (Nicotiana ssp.) while regulatory sequences from important agronomic crops, such as soybean (Glycine max), common bean (Phaseolus vulgaris), and cotton (Gossipium ssp.), are not widely reported. The pMtHP promoter of the Medicago truncatula PR-10 related gene drove GUS expression in different tissues and organs of $A$. thaliana at various developmental stages. The MtHP:::GUS expression was higher than the expression detected in CaMV35S:::GUS plants (Xiao et al., 2005). The $p V R$-ACS1 promoter naturally regulates the expression of an auxin-inducible ACC synthase gene (VR-ACS1) in $V$. radiata $L$. (mung bean). In situ assays in tobacco and Arabidopsis showed 4- to 6- fold higher protein levels for both GUS and luciferase compared with pCaMV35-constructs (Cazzonelli et al., 2005), highlighting a better performance of plant-specific constitutive promoters compared with viral promoters.

The soybean ( $G$. max) polyubiquitin promoter ( $p G m U b i)$ was evaluated by driving GFP expression in stably transformed soybean. Tissues carrying pGmUbi:::GFP showed a 2- to 5 -fold increase in gene expression compared to constructs containing the pCaMV35S promoter (Chiera et al., 2007; Hernandez-Garcia et al., 2009). Recently, the upstream regulatory region of the GmUBC4 gene was isolated from soybean by TAIL-PCR, uncovering a plant inducible promoter designated pUceS8.3, which has been cloned and patented for using in plant expression vectors (Grossi-de-Sa et al., 2013). The core promoter of pUceS8. 3 exhibits a sequence motif pattern, as the presence of the TATA-Box, CAT-Box, initiator element (Inr) consensus, and low GC content, characteristic of TATA-containing promoters. In silico analysis of pUces8. 3 cisacting elements showed the presence of hundreds of DNA motifs and its ability to drive gene expression was reported in different tissues of $A$. thaliana, including root, stem, leaf, and flower bud (Grossi de Sa et al., 2013). 
Table 1. Constitutive promoters of monocot plants used in transgenic plants.

\begin{tabular}{|c|c|c|c|c|c|}
\hline Source & Host & Promoter & Reporter Gene & Comments & Ref. \\
\hline $\begin{array}{l}\text { Oryza sativa } \\
\text { (rice) }\end{array}$ & O. sativa (rice) & pOsActin1 & GUS & $\begin{array}{l}\text { High levels of reporter gene expression in } \\
\text { transformed rice protoplasts. }\end{array}$ & $\begin{array}{l}\text { McElroy et al. } \\
(1990)\end{array}$ \\
\hline $\begin{array}{l}\text { Zea mays } \\
\text { (maize) }\end{array}$ & $\begin{array}{l}\text { Nicotiana } \\
\text { tabacum } \\
\text { (tobacco) }\end{array}$ & $\begin{array}{l}\text { Alcohol } \\
\text { dehydrogenase } \\
(p A d h-1)\end{array}$ & GUS & $\begin{array}{l}\text { Mainly induced in roots after } 24 \mathrm{~h} \text { of anaerobic } \\
\text { treatment (up to } 81 \text {-fold). }\end{array}$ & $\begin{array}{l}\text { Kyozuka et al. } \\
\text { (1991) }\end{array}$ \\
\hline Z. mays (maize) & $\begin{array}{l}\text { Z. mays (maize) } \\
\text { and N. tabacum } \\
\text { (tobacco) }\end{array}$ & $\begin{array}{l}\text { Ubiquitin } \\
\text { (pZmUbi1 and } \\
\text { pZmUbi2) }\end{array}$ & $\begin{array}{l}\text { Chloramphenicol } \\
\text { acetyl } \\
\text { transferase } \\
\text { (CAT) }\end{array}$ & $\begin{array}{l}\text { CAT assays of protoplasts extracts indicated higher } \\
\text { expression in monocot maize ( } 10 \text {-fold increase) } \\
\text { than in dicot tobacco (one-tenth the level) } \\
\text { compared with pCaMV35S constructs. }\end{array}$ & $\begin{array}{l}\text { Christensen et al. } \\
\text { (1992) }\end{array}$ \\
\hline O. sativa (rice) & O. sativa (rice) & pOsActin1 & $\operatorname{CrylA}(b)$ & $\begin{array}{l}\text { Cry1Ab content varied in the tissues and organs } \\
\text { studied; protein levels in leaves and stems were } \\
\text { similar for pCaMV35S and pOsActin1 promoter } \\
\text { plants. }\end{array}$ & Datta et al. (1998) \\
\hline O. sativa (rice) & O. sativa (rice) & $\mathrm{pOsCc1}$ & GFP & $\begin{array}{l}\text { Displayed particular high activity in calli and roots } \\
\text { with } 3 \text {-fold higher potential than the pOsAct } 1 \\
\text { promoter and comparable expression to the light- } \\
\text { regulated RbcS promoter in leaves. }\end{array}$ & Jang et al. (2002) \\
\hline Z. mays (maize) & $\begin{array}{l}\text { Triticum } \\
\text { aestivum } \\
\text { (wheat) } \\
\text { and Z. mays } \\
\text { (maize) }\end{array}$ & $\mathrm{pH} 2 \mathrm{~B}$ & GUS & $\begin{array}{l}\text { Wheat: stronger expression in floral tissues and } \\
\text { in the young part of leaves and roots; Maize: } \\
\text { stronger activity in leaves and roots. }\end{array}$ & $\begin{array}{l}\text { Rasco-Gaunt et al. } \\
\text { (2003) }\end{array}$ \\
\hline O. sativa (rice) & O. sativa (rice) & $\begin{array}{l}\text { pOsUbi1 and } \\
\text { pOsUbi2 }\end{array}$ & GUS & $\begin{array}{l}\text { Activity levels were } 8 \text { to } 35 \text {-fold higher in } \\
\text { transgenic rice, respectively, compared with the } \\
\text { pCaMV35S construct. }\end{array}$ & $\begin{array}{l}\text { Wang \& Oard } \\
(2003)\end{array}$ \\
\hline Palm oil & $\begin{array}{l}\text { Palm oil and } \\
\text { N. tabacum } \\
\text { (tobacco) }\end{array}$ & $\begin{array}{l}\text { Ubiquitin } \\
\text { extension } \\
\text { protein (pUep1) }\end{array}$ & GUS & $\begin{array}{l}\text { Transient expression in all palm oil tissues tested } \\
\text { and in tobacco. The highest potential was found } \\
\text { for pZmUbi1, pCaMV35S, and pUep1 constructs. }\end{array}$ & $\begin{array}{l}\text { Masura et al. } \\
(2010)\end{array}$ \\
\hline $\begin{array}{l}\text { Panicum } \\
\text { virgatum } \\
\text { (switchgrass) }\end{array}$ & $\begin{array}{l}\text { P. virgatum } \\
\text { (switchgrass), } \\
\text { O. sativa (rice) } \\
\text { and } N . \text { tabacum } \\
\text { (tobacco) }\end{array}$ & $\begin{array}{l}\text { pPvUbi1/ } \\
\text { pPvUbi2 }\end{array}$ & GUS & $\begin{array}{l}\text { Strong constitutive expression in all plants } \\
\text { analyzed, being good candidates for monocot and } \\
\text { dicot transformation. }\end{array}$ & Mann et al. (2011) \\
\hline O. sativa (rice) & O. sativa (rice) & $\begin{array}{l}p A P X, p P G D 1 \\
\text { and } p R 1 G 1 B\end{array}$ & GFP & $\begin{array}{l}\text { High activity in the whole plant at vegetative and } \\
\text { reproductive stages, but low activity specifically } \\
\text { in ovary and pistil filaments. }\end{array}$ & Park et al. (2012) \\
\hline $\begin{array}{l}\text { O. sativa (rice), } \\
\text { Z. mays (maize) }\end{array}$ & O. sativa (rice) & $\begin{array}{l}\text { pOsUbi1 and } \\
\text { pZmUbi1 }\end{array}$ & GUS & $\begin{array}{l}\text { Higher expression when using rice pOsUbi1 } \\
\text { promoter than the maize } p Z m U b i 1 .\end{array}$ & $\begin{array}{l}\text { Bhattacharyya et al. } \\
\text { (2012) }\end{array}$ \\
\hline O. sativa (rice) & O. sativa (rice) & $\begin{array}{l}\text { Gibberellic } \\
\text { acid insensitive } \\
(p G A l)\end{array}$ & GUS & $\begin{array}{l}\text { GUS expression was lower than the rice and maize } \\
\text { pZmUbi } 1 \text { promoters. }\end{array}$ & $\begin{array}{l}\text { Bhattacharyya et al. } \\
\text { (2012) }\end{array}$ \\
\hline $\begin{array}{l}\text { Brachypodium } \\
\text { distachyon }\end{array}$ & Z. mays (maize) & $\begin{array}{l}\text { pEF1 } a \text { and } \\
\text { pUB110 }\end{array}$ & GUS & $\begin{array}{l}\text { pUBI10-GUS plants contained 6- to } 14 \text {-fold more } \\
\text { GUS protein, whereas the pEF1a-GUS plants had } \\
\text { 3- to } 6 \text {-fold more protein than the pCaMV35S } \\
\text { construct. }\end{array}$ & $\begin{array}{l}\text { Coussens et al. } \\
(2012)\end{array}$ \\
\hline $\begin{array}{l}\text { Ananas comosus } \\
\text { (pineapple) }\end{array}$ & A. thaliana & pSUI1 and pL36 & GUS & $\begin{array}{l}\text { GUS expression in all tissues at similar levels of } \\
\text { pCaMV35S. }\end{array}$ & Koia et al. (2013) \\
\hline $\begin{array}{l}\text { Marchantia } \\
\text { polymorpha }\end{array}$ & M. polymorpha & pMpEF1a & GUS & $\begin{array}{l}\text { Strong meristematic expression and greater } \\
\text { activity in female sexual tissues. }\end{array}$ & $\begin{array}{l}\text { Althoff et al. } \\
\text { (2014) }\end{array}$ \\
\hline O. sativa (rice) & O. sativa (rice) & pOsCon1 & GUS & $\begin{array}{l}\text { Comparable activity to pOsCc1, pOsAct } 1 \text {, or } \\
\text { pZmUbi promoters in most tissues, but more } \\
\text { active than the pCAMV35S promoter in roots, } \\
\text { seeds, and calli. }\end{array}$ & Li et al. (2014) \\
\hline
\end{tabular}


Table 2. Constitutive promoters of eudicot plants used in transgenic plants.

\begin{tabular}{|c|c|c|c|c|c|}
\hline Source & Host & Promoter & Reporter Gene & Comments & Ref. \\
\hline $\begin{array}{l}\text { N. tabacum } \\
\text { (tobacco) }\end{array}$ & $\begin{array}{l}\text { N. tabacum } \\
\text { (tobacco) }\end{array}$ & ptCUP & GUS & $\begin{array}{l}\text { Activity detected in all organs studied, being } \\
\text { at similar levels in leaves of } p t C U P \text { and } \\
\text { pCaMV35S plants. }\end{array}$ & $\begin{array}{l}\text { Foster et al. } \\
\text { (1999) }\end{array}$ \\
\hline A. thaliana & $\begin{array}{l}\text { N. tabacum } \\
\text { (tobacco) }\end{array}$ & $\begin{array}{l}\text { PPTSB1 and } \\
\text { PPPHYB }\end{array}$ & GUS & $\begin{array}{l}\text { Both promoters showed } 50 \% \text { or more activity } \\
\text { compared to } p \text { CaMV } 355 \text { promoter }\end{array}$ & $\begin{array}{l}\text { Shirasawa- } \\
\text { Seo et al. (2002) }\end{array}$ \\
\hline $\begin{array}{l}\text { N. tabacum } \\
\text { (tobacco) }\end{array}$ & $\begin{array}{l}\text { N. tabacum } \\
\text { (tobacco) }\end{array}$ & $\begin{array}{l}\text { Polyubiquitin } \\
\text { (Tubi.u4) }\end{array}$ & $\begin{array}{l}\text { Chloramphenicol } \\
\text { acetyl transferase } \\
\text { (CAT) }\end{array}$ & $\begin{array}{l}\text { CAT expression was almost twice as high as } \\
\text { pCaMV35S in the leaves evaluated. }\end{array}$ & Kang et al. (2003) \\
\hline A. thaliana & $\begin{array}{l}\text { Allocasuarina } \\
\text { verticillata }\end{array}$ & pUBQ1 & GUS & $\begin{array}{l}\text { The } p U B Q 1 \text { and } p C a M V 35 S \text { promoters } \\
\text { were minimally active, with } p U B Q 1 \text { being } \\
\text { inadequate for } A \text {. verticillata. }\end{array}$ & $\begin{array}{l}\text { Obertello et al. } \\
(2005)\end{array}$ \\
\hline M. truncatula & $\begin{array}{l}\text { M. truncatula, } \\
\text { A. thaliana and } \\
\text { Trifolium repens } \\
\text { (white clover) }\end{array}$ & pMtHP & GUS & $\begin{array}{l}\text { Expression detected in all tissues analyzed } \\
\text { generally similar to or higher than that of } \\
\text { pCaMV35S-GUS plants. }\end{array}$ & Xiao et al. (2005) \\
\hline $\begin{array}{l}\text { Vigna radiata } \\
\text { (Mung bean) }\end{array}$ & $\begin{array}{l}\text { N. tabacum } \\
\text { (tobacco) } \\
\text { and A. thaliana }\end{array}$ & pVR-ACS1 & GUS/Luciferase & $\begin{array}{l}\text { Protein and expression levels were generally } \\
\text { 4-to } 6 \text {-fold higher for both reporter genes } \\
\text { in comparison with plants containing the } \\
\text { pCaMV35S. }\end{array}$ & $\begin{array}{l}\text { Cazzonelli et al. } \\
(2005)\end{array}$ \\
\hline $\begin{array}{l}\text { G. } \max \\
\text { (soybean) }\end{array}$ & $\begin{array}{l}\text { Phaseolus lunatus } \\
\text { (Lima bean) }\end{array}$ & $\begin{array}{l}\text { Polyubiquitin } \\
\text { (pGmubi) and } \\
\text { pGmHSP9OL }\end{array}$ & GFP & $\begin{array}{l}\text { pGmubi with and without its intronic region } \\
\text { displayed 5- and 2- fold higher expression } \\
\text { compared with } p C a M V 35 S \text {, respectively. The } \\
\text { full-length pGmHSP9OL promoter displayed 4- } \\
\text { times increase in activity. }\end{array}$ & $\begin{array}{l}\text { Chiera et al. } \\
(2007)\end{array}$ \\
\hline $\begin{array}{l}\text { G. } \max \\
\text { (soybean) }\end{array}$ & $\begin{array}{l}\text { G. } \max \\
\text { (soybean) }\end{array}$ & $\begin{array}{l}\text { Polyubiquitin } \\
\text { (pGmubi) }\end{array}$ & GFP & $\begin{array}{l}\text { pGmubi-GFP plants generally had higher GFP } \\
\text { expression than } p C a M V 35 S \text {-GFP plants. }\end{array}$ & $\begin{array}{l}\text { Hernandez- } \\
\text { Garcia et al. } \\
(2009)\end{array}$ \\
\hline $\begin{array}{l}\text { G. hirsutum } \\
\text { (cotton) }\end{array}$ & A. thaliana & pUceA1.7 & GUS & $\begin{array}{l}\text { Expression levels were equal to or higher than } \\
\text { those of } p C a M V 355 \text {. Activity was } 7 \text {-fold higher } \\
\text { in flowers, } 2 \text {-fold in roots and similar in leaves } \\
\text { and stems. }\end{array}$ & $\begin{array}{l}\text { Viana et al. } \\
\text { (2011) }\end{array}$ \\
\hline $\begin{array}{l}\text { Populus } \\
\text { tomentosa }\end{array}$ & $\begin{array}{l}\text { A. thaliana and } \\
\text { N. tabacum } \\
\text { (tobacco) }\end{array}$ & pPtMCP & GUS & $\begin{array}{l}\text { Activity detected in all tissues and organs } \\
\text { studied, but at lower levels than in pCaMV35s- } \\
\text { GUS plants. }\end{array}$ & Chen et al. (2013) \\
\hline A. thaliana & A. thaliana & pAtTCTP & GUS & $\begin{array}{l}\text { Small }(0.3 \mathrm{~kb}) \text { promoter with high activity in } \\
\text { all tissues, representing } ~ 55 \% \text { of the reporter } \\
\text { gene expression in pCaMV35S-GUS plants. }\end{array}$ & Han et al. (2015) \\
\hline A. thaliana & $\begin{array}{l}\text { Agrostis } \\
\text { stolonifera } \\
\text { (creeping } \\
\text { bentgrass) }\end{array}$ & PTCTP & $B A R$ & $\begin{array}{l}\text { High BAR expression in all tissues, } \\
\text { corresponding to } \sim 46-86 \% \text { of that in } \\
\text { pCaMV35S-BAR plants. }\end{array}$ & Han et al. (2015) \\
\hline Jatropha curcas & $\begin{array}{l}\text { J. curcas and } A \text {. } \\
\text { thaliana }\end{array}$ & pJCUEP & GUS & $\begin{array}{l}\text { pJcUEP and } p C a M V 35 S \text { had similar activities in } \\
\text { stems, mature leaves and female flowers, but } \\
\text { pCaMV35S was more effective in young leaves } \\
\text { and inflorescences. }\end{array}$ & Tao et al. (2015) \\
\hline $\begin{array}{l}\text { Chrysanthemum } \\
\text { morifolium } \\
\text { (White Wing) }\end{array}$ & $\begin{array}{l}\text { A. thaliana and } \\
\text { C. morifolium }\end{array}$ & pCmActin & GUS & $\begin{array}{l}\text { Higher GUS expression in } C \text {. morifolium } \\
\text { compared to pCaMV } 35 \mathrm{~S} \text { and exhibited similar } \\
\text { activity in all } A \text {. thaliana tissues, not being } \\
\text { detected in seeds. }\end{array}$ & Hong et al. (2016) \\
\hline $\begin{array}{l}\text { G. hirsutum } \\
\text { (cotton) }\end{array}$ & $\begin{array}{l}\text { N. tabacum } \\
\text { (tobacco) }\end{array}$ & pGhEF1A1.7 & GUS & $\begin{array}{l}\text { Activity was higher in leaves and stems and } \\
\text { similar in flower and roots using pCaMV } 35 \mathrm{~S} \text { as } \\
\text { a comparison. }\end{array}$ & Sun et al. (2016) \\
\hline
\end{tabular}


Table 2. Continued...

\begin{tabular}{|c|c|c|c|c|c|}
\hline Source & Host & Promoter & Reporter Gene & Comments & Ref. \\
\hline $\begin{array}{l}\text { Solanum } \\
\text { tuberosum } \\
\text { (potato) }\end{array}$ & $\begin{array}{l}\text { A. thaliana, } \\
\text { S. tuberosum, } \\
\text { N. tabacum, } \\
\text { Cucumis sativus } \\
\text { (cucumber), } \\
\text { Vitis vinifera } \\
\text { (grape) and H. } \\
\text { vulgare (barley), } \\
\text { Citrus sinensis } \\
\text { (sweet orange) } \\
\text { and Solanum } \\
\text { lycopersicum } \\
\text { (tomato) }\end{array}$ & pKST1 & $G F P$ & $\begin{array}{l}\text { Exhibited guard cell expression in all species } \\
\text { evaluated, being the first dicot-originated } \\
\text { guard cell promoter active in monocots. }\end{array}$ & Kelly et al. (2017) \\
\hline A. thaliana & N. benthamiana & $\begin{array}{l}\text { pAtSCPL30 } \\
\text { fragments }\end{array}$ & GUS & $\begin{array}{l}\text { Strong activity in almost all tissues, displaying } \\
2 \text { times more transgene expression than the } \\
\text { pCaMV35S. }\end{array}$ & Jiang et al. (2018) \\
\hline $\begin{array}{l}\text { C. sinensis } \\
\text { (sweet orange) }\end{array}$ & $\begin{array}{l}\text { C. sinensis } \\
\text { (sweet orange) }\end{array}$ & $\begin{array}{l}p C s C Y P \\
p C s G A P C 2, \\
p C s E F 1\end{array}$ & GUS & $\begin{array}{l}\text { mRNA levels were up to } 60-41.8 \% \text { of the value } \\
\text { obtained for pCaMV35S in leaves, stems, and } \\
\text { roots. }\end{array}$ & $\begin{array}{l}\text { Erpen et al. } \\
(2018)\end{array}$ \\
\hline $\begin{array}{l}\text { G. hirsutum } \\
\text { (cotton) }\end{array}$ & $\begin{array}{l}\text { G. hirsutum } \\
\text { (cotton) }\end{array}$ & pGhSCFP & $\begin{array}{l}\text { Expansin } \\
\text { (CpEXPA1) }\end{array}$ & $\begin{array}{l}\text { Activity was higher in cotton fibers than in } \\
\text { other parts of the plant, whereas pCaMV35S- } \\
\text { driven expression was low in fibers but } \\
\text { continuous in all tissues. }\end{array}$ & $\begin{array}{l}\text { Yaqoob et al. } \\
(2020)\end{array}$ \\
\hline $\begin{array}{l}\text { C. sinensis (sweet } \\
\text { orange) }\end{array}$ & N. benthamiana & $\begin{array}{l}\text { pCsGAPC2, } \\
\text { pCsEF1 and } \\
\text { fragments }\end{array}$ & GUS & $\begin{array}{l}p C s C Y P \text { promoter activity was not affected by } \\
\text { any deletion. Truncated fragments of } p C s E F 1 \\
\text { had higher GUS expression in leaves. }\end{array}$ & $\begin{array}{l}\text { Corte et al. } \\
(2020)\end{array}$ \\
\hline
\end{tabular}

From cotton (Gossypium hirsutum), the pGhEF1A1.7promoter with its 5'-untranslated region (5'UTR) was transcriptionally fused to the uidA reporter gene and evaluated in tobacco. The reported gene activity was remarkably higher in leaves and stems compared to pCaMV35S::GUS plants and similar to pCaMV35S in flowers and roots (Sun et al., 2016). Likewise, the pUceA1.7 cotton promoter resulted in 7-fold higher GUS expression in flowers, 2 -fold higher expression in roots, and similar expression levels in leaves and stems compared to pCaMV35S (Viana et al., 2011; Basso et al., 2020). Higher gene expression levels in flowers are particularly useful in cotton since its floral buds are attacked by the coleopteran Anthonomus grandis, the cotton boll weevil (CBW). The coleopteran insect lays eggs into the floral buds, and the larva develops by feeding on their reproductive structures, impairing fiber production (Ribeiro et al., 2021). Recently, Moura et al. (2021) have described two uncharacterized cotton promoters, pGhERF105 and pGhNc-HARBI1, highly responsive to $C B W$ infestation and active in vegetative and reproductive tissues, potentially applied to insect-pest control. A complete list of eudicots constitutively expressed promoters can be found in Table 2 .

\section{Inducible/regulated plant promoters responsive to biotic stresses}

Plants are constantly exposed to biotic stresses, such as insects, nematodes, fungi, bacteria, and viruses. Insect attack and pathogen infection can induce plant defense mechanisms by activating or inhibiting the expression of different genes that are regulated through the activity of their respective promoters and transcription factors (Figure 1). With the advances in transcriptome sequencing, it has been possible to identify many genes induced by biotic stresses that may have numerous biotechnological applications in basic and applied research (Dong et al., 2018; Shukla et al., 2018; Koch et al., 2020; Ren et al., 2020). Moreover, a detailed study of promoters driving expression and regulation of biotic stress-responsive genes has identified attractive promoters with the potential to be used in the development of efficient transgenic plants resistant to several economically important insect-pests and pathogens that threaten global food production (Baruah et al., 2020). Promoters of defense-related genes induced by biotic stresses are of particular interest to plant improvement research and have been explored for use in genetically engineered plants for regulation of 


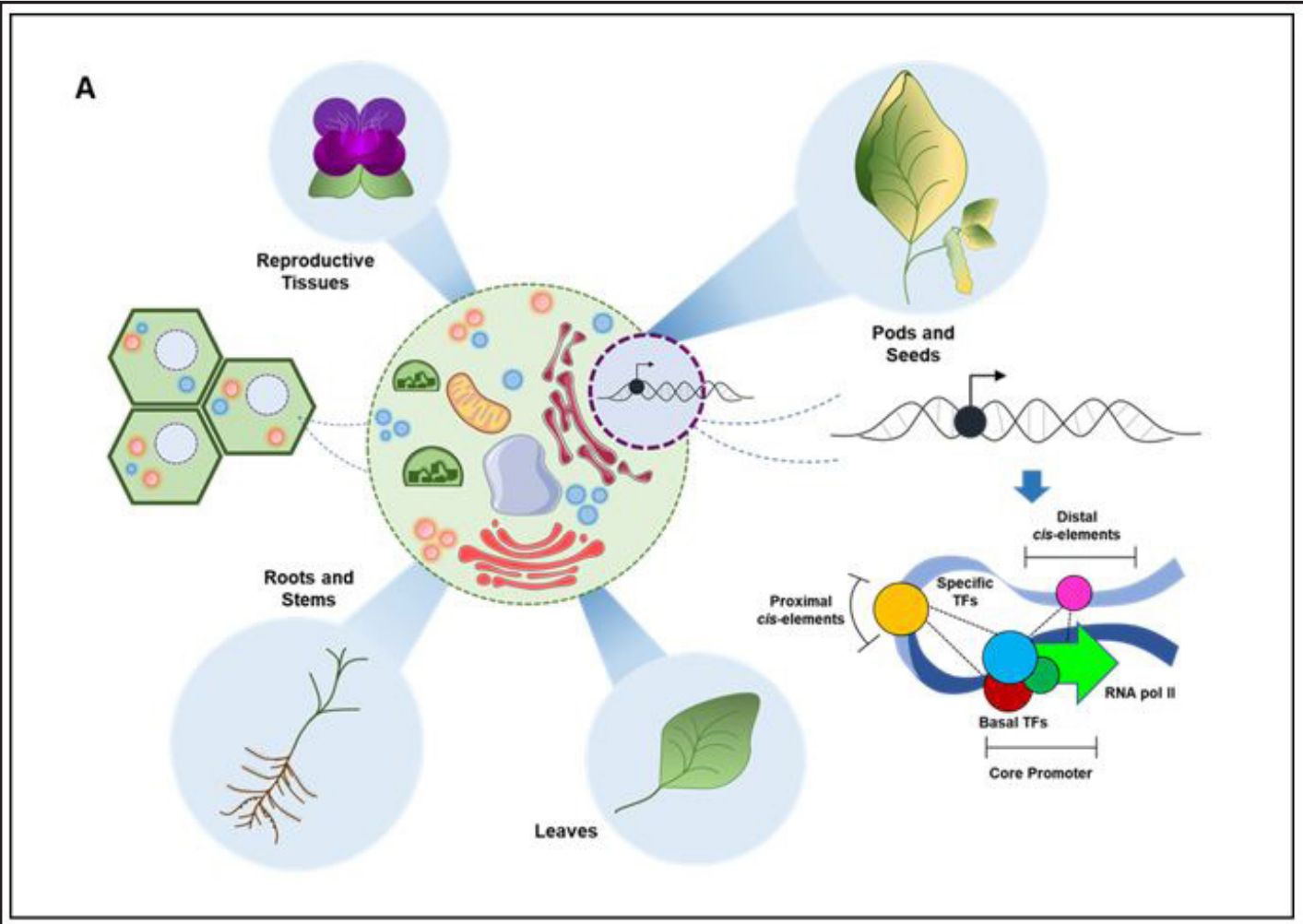

B

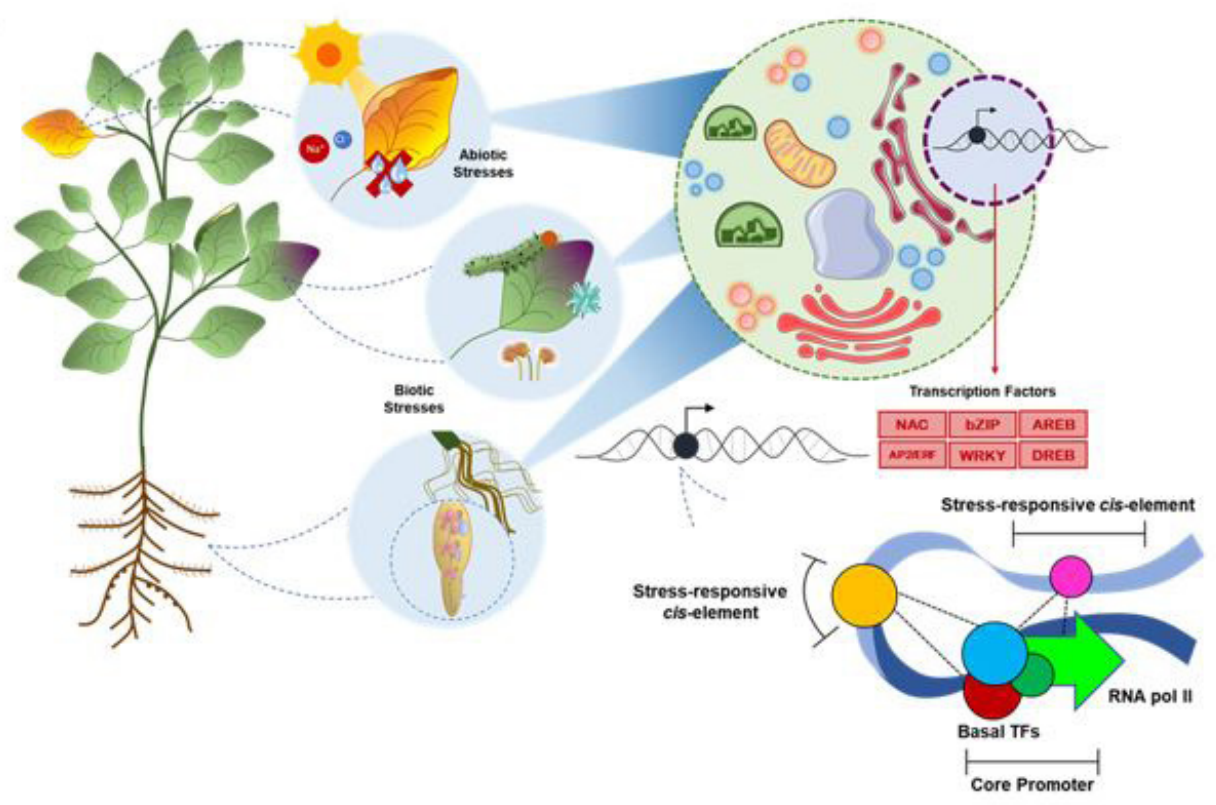

Figure 1. Schematic diagram of gene expression control by constitutive and inducible promoters in plants. (A) Gene expression controlled by constitutive promoters. Basal transcription factors recognize canonical cis-elements in core promoters as well as in proximal and distal regulatory regions. By multiple protein-protein and protein-DNA interactions, the regulatory region is sterically adjusted to accommodate the transcription factors and other pre-initiation complexes (PIC) proteins in the transcription bubble. Conceptually, constitutive promoters allow the expression in most plant tissues, independent of environmental conditions, leading to high levels of gene expression and protein accumulation in engineered plants; (B) Stress-inducible promoters respond to multiple environmental signals, usually coordinated by phytohormones. Facing some abiotic or biotic adversity, plants release hormones, such as ABA, JA, SA, and ETH, which stimulate the transcription of stress-responsive TFs. These TFs recognize specific cis-actin elements in promoter regions and, collectively, drive gene expression. Mechanistically, the transcription initiation coordinated by constitutive and inducible promoters is the same. The difference between the two stems from the dependence on specific TFs, whose expression varies with plant tissues, developmental stage, and environmental signals. 
transgene expression (Gurr \& Rushton 2005; Ali \& Kim 2019; Kummari et al., 2020).

An ideal promoter should have a strong response against a broad spectrum of pathogens and/or insect-pests and be rapidly induced in response to the biotic stress. The major advantage of the stress-inducible promoters over the constitutive promoters is the suppression of the transgene expression upon repression of biotic stress stimuli to avoid unnecessary energy consumption that is required for other plant physiological processes and, consequently, any fitness penalty in plant growth and development (Kasuga et al., 2004; Nakashima et al., 2007; Quilis et al., 2014; Boni et al., 2018).

Thus, inducible promoters must drive an absence or very low levels of basal background expression in the plant to ensure successful plant protection from insects and pathogens. Although the availability of identified inducible promoters is relatively low, some promoters are increasingly used for transgene expression in plants (Quilis et al., 2014; Liu et al., 2019; Pandey et al., 2019). In addition, characterization of inducible promoters and identification of key pathogeninducible cis-acting elements have enabled the engineering of diverse types of synthetic inducible promoters that have also been employed in the development of elite crops (Ali \& Kim, 2019). More importantly, regulated promoters allow for the direction of gene expression only in specific organs, such as roots and flowers, thereby limiting the ectopic protein accumulation at the site of pathogens infection (Singhal et al., 2016). Hence, each application must be evaluated separately to select the best available promoter and decide on the best strategy, tailored to specific pathosystems, resulting in a perfect balance between agronomic and molecular characteristics. Previously described inducible promoters in plants are described in Table 3, and the following sections describe relevant features of promoters responsive to the major biotic stress conditions faced by plants.

\section{Insect-inducible promoters}

Several inducible promoters have been explored to engineer insect-resistant transgenic plants. Pandey et al. (2019) demonstrated that Arabidopsis transgenic lines expressing GUS under the control of the rose $R b P C D 1$ promoter were strongly wound-inducible by $H$. armigera and $M$. persicae as early as $5 \mathrm{~h}$ after insect infestation. In addition, strong wound-inducible GUS expression was observed in stably transformed chickpea leaves and transiently agroinfiltrated cotton sepals, rose petals, gladiolus tepals, and tobacco leaves, indicating that it is active in a wide range of plant species. Moreover, the $R b P C D 1$ promoter was evaluated to drive Cry1Ac gene expression in Arabidopsis and tomato transgenic plants, leading to a 4.5- to 27-fold increase in Cry1Ac expression in the transgenic lines compared with lines under CaMV35 promoter control. Phenotypically, the transgenic plants exhibited higher insect mortality and a stable protective effect against insect-pest attacks (Pandey et al., 2019).

Similarly, the expression of GUS and GFP reporter genes under the control of the S. humilis peroxidase (Shpx6b) gene promoter was induced in transgenic tobacco plants in response to the attack by the chewing and sucking insects Phthorimaea operculella and M. persicae, indicating that the Shpx6b promoter may be useful for the development of transgenic plants resistant to insect-pests (Perera \& Jones, 2004). Godard et al. (2007) showed that the potato proteinase inhibitor II (Pinll) promoter was able to drive the woundand insect-inducible GUS expression in Picea glauca (white spruce), Arabidopsis, or tobacco. Li et al. (2020) observed that the rice hydroperoxide lyase (OsHPL2) gene promoter was significantly upregulated after herbivory of $C$. suppressalis, but not after feeding of Nilaparvata lugens, mechanical wounding, abscisic acid, jasmonic acid or salicylic acid treatments. Despite the advantages of inducible promoters over constitutive promoters that have been widely used in the genetic engineering of many plants, the trade-offs between inducibility and strength should be considered for practical biotechnological application.

\section{Nematode-inducible promoters}

Inducible promoters have also been explored to improve plant tolerance to phytonematodes. For instance, the promoters of the NRRS genes from Arabidopsis, At1g74770 and At $2 g 18140$, were used in the development of transgenic Arabidopsis expressing the GUS reporter gene. Bioassays with the transgenic plants revealed that both promoters were responsive to the root-knot nematode (RNK) $M$. incognita, regulating GUS activity in roots and galls (Kakrana et al., 2017). Using a similar experimental strategy, Mitchum et al. (2004) evaluated a nematode-inducible promoter that is expressed in roots. Tobacco and Arabidopsis lines harboring the Arabidopsis endo-1,4-B-glucanase (Cel1) promoter transcriptionally fused to the uid $A$ gene were infected with $M$. incognita, Globodera tabacum and $H$. schachtii. The authors observed Cel1-driven GUS expression in the giant-cells of the tobacco roots infected with $M$. incognita 11-13 days after inoculation, but GUS expression was not detected in syncytia of the tobacco or Arabidopsis roots induced by G. tabacum and $H$. schachtii, respectively.

Other promoters from genes related to defensive pathways were also explored to achieve application for nematode tolerance. The Hahsp17.7G4 gene encodes a small heat shock protein involved in embryogenesis and stress responses. The validation of the sunflower Hahsp17.7G4 promoter demonstrated that it was responsible for mediating high GUS expression in tobacco galls, particularly in the latter stages of $M$. incognita infection, but not in other root regions. Furthermore, the nematode-inducible promoter regulated GUS activity primarily in giant cells (Escobar et al., 2003). These studies demonstrated preferential or specific induction of promoters in the gall or syncytia structures upon nematode infection by bioassays performed in transgenic plants.

\section{Fungus-inducible promoters}

Over the past decade, various plant promoters have been tested to regulate gene expression upon plant-pathogenic fungi. Himmelbach et al. (2010) isolated and functionally analyzed the barley GER4C gene promoter. Strong transient expression of GUS under the control of the GER4C promoter was observed in barley leaves inoculated with $B$. graminis f. sp. hordei. To further evaluate the promoter, the authors stably introduced it into barley transgenic lines. Bioassays 
Table 3. Insect/Pathogen-responsive promoters isolated from plants.

\begin{tabular}{|c|c|c|c|c|c|}
\hline Gene (s) & Promoter (s) & $\begin{array}{c}\text { Source of the } \\
\text { promoter }\end{array}$ & $\begin{array}{l}\text { Insect/Pathogen } \\
\text { responsible for the } \\
\text { induction }\end{array}$ & Reporter gene & Ref. \\
\hline RbPCD1 gene & RbPCD1 promoter & Rosa bourboniana & $\begin{array}{l}\text { Helicoverpa armigera, } \\
\text { Myzus persicae }\end{array}$ & GUS & Pandey et al. (2019) \\
\hline $\begin{array}{l}\text { peroxidase gene } \\
(\text { Shpx6b) }\end{array}$ & Shpx6b promoter & Stylosanthes humilis & $\begin{array}{l}\text { Phthorimaea } \\
\text { operculella, M. } \\
\text { persicae }\end{array}$ & GUS/GFP & Perera \& Jones (2004) \\
\hline $\begin{array}{l}\text { proteinase inhibitor } \\
\text { II (pinll) }\end{array}$ & pinll promoter & S. tuberosum & $\begin{array}{l}\text { Bradysia spp., Pissodes } \\
\text { strobi }\end{array}$ & GUS & Godard et al. (2007) \\
\hline $\begin{array}{l}\text { hydroperoxide lyase } \\
\text { gene (OsHPL2) }\end{array}$ & OsHPL2 promoter & O. sativa & Chilo suppressalis & GUS & Li et al. (2020) \\
\hline $\begin{array}{l}\text { putative subtilisin/ } \\
\text { chymo-trypsin } \\
\text { inhibitor }\end{array}$ & B1-A04 promoter & O. sativa & C. suppressalis & GUS & Hua et al. (2007) \\
\hline $\begin{array}{l}\text { flavin-containing } \\
\text { monooxygenase } \\
\text { (W250), speckle-type } \\
\text { POZ protein }(A 360) \text {, } \\
\text { early flowering } 4 \\
(A 080)\end{array}$ & $\begin{array}{l}\text { W250 promoter, } \\
\text { A360 promoter, } A 080 \\
\text { promoter }\end{array}$ & A. thaliana & $\begin{array}{l}\text { Bemisia tabaci } \\
\text { (W250 promoter), M. } \\
\text { persicae (A360 and } \\
\text { A080 promoters) }\end{array}$ & GUS & Dubey et al. (2018) \\
\hline Hahsp17.7G4 gene & Hahsp17.7G4 promoter & Helianthus annuus & M. incognita & GUS & Escobar et al. (2003) \\
\hline AT1G26530 gene & AT1G26530 promoter & A. thaliana & M. incognita & GUS & Kumar et al. (2016) \\
\hline Hs $1^{\text {pro-1 }}$ gene & Hs $1^{\text {pro-1 }}$ promoter & Beta vulgaris & Heterodera schachtii & GUS & Thurau et al. (2003) \\
\hline $\begin{array}{l}\text { CYP97A29, DFR, FLS, } \\
\text { NIK and PMEI genes }\end{array}$ & $\begin{array}{l}\text { CYP97A29 promoter, } \\
\text { DFR promoter, } \\
\text { FLS promoter, NIK } \\
\text { promoter, PMEI } \\
\text { promoter }\end{array}$ & S. lycopersicum & $\begin{array}{l}\text { Globodera } \\
\text { rostochiensis }\end{array}$ & GUS & $\begin{array}{l}\text { Wiśniewska et al. } \\
\text { (2013) }\end{array}$ \\
\hline $\begin{array}{l}\text { endo-B-1,4-glucanase } \\
\text { (cellulase) gene }\end{array}$ & NtCel7 promoter & N. tabacum & $\begin{array}{l}\text { H. glycines, } M . \\
\text { incognita, H. } \\
\text { schachtii, G. tabacum }\end{array}$ & GUS & Wang et al. (2007) \\
\hline pyk20 gene & pyk20 promoter & A. thaliana & H. schachtii & GUS & Puzio et al. (2000) \\
\hline $\begin{array}{l}\text { cel1 endo 1,4 B } \\
\text { glucanase gene } \\
\text { (Atcel1) }\end{array}$ & Atcel1 promoter & A. thaliana & M. incognita & GUS & Sukno et al. (2006) \\
\hline $\begin{array}{l}\text { Cel1 endo-1,4-B } \\
\text { glucanase gene }\end{array}$ & Cel1 promoter & A. thaliana & M. incognita & GUS & Mitchum et al. (2004) \\
\hline LEMMI9 gene & LEMMI9 promoter & S. lycopersicum & M. incognita & GUS & Escobar et al. (1999) \\
\hline wun1 gene & wun1 promoter & S. tuberosum & $\begin{array}{l}\text { G. pallida, M. } \\
\text { javanica, }\end{array}$ & GUS & Hansen et al. (1996) \\
\hline germin-like GER4 gene & GER4C promoter & H. vulgare & $\begin{array}{l}\text { Blumeria graminis } \\
\text { f. sp hordei } B . \\
\text { graminis } \mathrm{f} \text {. sp tritici, } \\
\text { Rhynchosporium } \\
\text { secalis }\end{array}$ & GUS & $\begin{array}{l}\text { Himmelbach et al. } \\
(2010)\end{array}$ \\
\hline $\begin{array}{l}\text { polyphenol oxidase } 12 \\
\text { gene (GmaPPO12) }\end{array}$ & GmaPPO12 promoter & G. $\max$ & $\begin{array}{l}\text { Phytophthora sojae, } \\
\text { Phytophthora capsici }\end{array}$ & GUS & Chai et al. (2013) \\
\hline GRMZM2G174449 gene & $\begin{array}{l}\text { GRMZM2G174449 } \\
\text { promoter }\end{array}$ & Z. mays & Rhizoctonia solani & GUS/GFP & Yang et al. (2017b) \\
\hline CYP76M7 gene & CYP76M7 promoter & O. sativa & Magnaporthe oryzae & GUS & Vijayan et al. (2015) \\
\hline
\end{tabular}


Table 3. Continued...

\begin{tabular}{|c|c|c|c|c|c|}
\hline Gene (s) & Promoter (s) & $\begin{array}{c}\text { Source of the } \\
\text { promoter }\end{array}$ & $\begin{array}{l}\text { Insect/Pathogen } \\
\text { responsible for the } \\
\text { induction }\end{array}$ & Reporter gene & Ref. \\
\hline $\begin{array}{l}\text { senescence-associated } \\
\text { gene (SAG12, SAG13) }\end{array}$ & $\begin{array}{l}\text { SAG12 promoter, } \\
\text { SAG13 promoter }\end{array}$ & A. thaliana & $\begin{array}{l}\text { Botrytis cinerea } \\
\text { (SAG12 and SAG13 } \\
\text { promoters), } \\
\text { Trichoderma } \\
\text { harzianum T39S } \\
\text { (SAG13 promoter) }\end{array}$ & GUS & $\begin{array}{l}\text { Swartzberg et al. } \\
\text { (2008) }\end{array}$ \\
\hline $\begin{array}{l}\text { phenylalanine } \\
\text { ammonia-lyase } 1 \text { gene } \\
\text { (PAL1) }\end{array}$ & PAL1 promoter & A. thaliana & Peronospora parasitica & GUS & $\begin{array}{l}\text { Mauch-Mani \& } \\
\text { Slusarenko (1996) }\end{array}$ \\
\hline $\begin{array}{l}\text { osmotin-like protein } \\
\text { gene (OSML13, } \\
\text { OSML81) }\end{array}$ & $\begin{array}{l}\text { OSML13 promoter, } \\
\text { pOSML81 promoter }\end{array}$ & Solanum commersonii & P. infestans & GUS & Zhu et al. (1995) \\
\hline $\begin{array}{l}\text { puroindoline- } a \text { gene } \\
\text { (PinA) }\end{array}$ & PinA promoter & T. aestivum & Magnaporthe grisea & GUS & Evrard et al. (2007) \\
\hline OsNAC6 gene & OsNAC6 promoter & O. sativa & M. grisea & GUS & $\begin{array}{l}\text { Nakashima et al. } \\
\text { (2007) }\end{array}$ \\
\hline prp1-1 gene & prp1-1 promoter & S. tuberosum & P. infestans & GUS & $\begin{array}{l}\text { Hahn \& Strittmatter } \\
\text { (1994) }\end{array}$ \\
\hline Pgst1 gene & Pgst1 promoter & S. tuberosum & $\begin{array}{l}\text { Erwinia amylovora, } \\
\text { Venturia inaequalis }\end{array}$ & GUS & Malnoy et al. (2006) \\
\hline $\begin{array}{l}\text { ACC oxidase - LEACO1 } \\
\text { gene }\end{array}$ & LEAC01 promoter & S. lycopersicum & $\begin{array}{l}\text { Tobacco mosaic virus } \\
\text { (TMV), Cladosporium } \\
\text { fulvum, Powdery } \\
\text { mildew }\end{array}$ & GUS & $\begin{array}{l}\text { Blume \& Grierson } \\
\text { (1997) }\end{array}$ \\
\hline $\begin{array}{l}\text { plastid lipid- } \\
\text { associated protein } \\
\text { ChrC gene }\end{array}$ & ChrC promoter & C. sativus & $\begin{array}{l}\text { Sphaerotheca } \\
\text { fuliginea (Oidium sp.) }\end{array}$ & GUS & $\begin{array}{l}\text { Leitner-Dagan et al. } \\
\text { (2006) }\end{array}$ \\
\hline defensin PDF1.2 gene & PDF1.2 promoter & A. thaliana & $\begin{array}{l}\text { Alternaria } \\
\text { brassicicola, } B . \\
\text { cinerea }\end{array}$ & GUS & Manners et al. (1998) \\
\hline $\begin{array}{l}\text { anionic peroxidase } \\
\text { gene (tap1, tap2) }\end{array}$ & $\begin{array}{l}\text { tap1 promoter, tap2 } \\
\text { promoter }\end{array}$ & S. lycopersicum & $\begin{array}{l}\text { Fusarium solani f. } \\
\text { sp. pisi }\end{array}$ & GUS & Mohan et al. (1993) \\
\hline $\begin{array}{l}\text { calmodulin methyl } \\
\text { transferase gene } \\
\text { (At4g35987), } \\
\text { senescence associated } \\
\text { gene (At4g35985) }\end{array}$ & $\begin{array}{l}\text { At4g35987 promoter, } \\
\text { At4g35985 promoter }\end{array}$ & A. thaliana & Peronospora tabacina & GUS/GFP & Banerjee et al. (2013) \\
\hline $\begin{array}{l}\text { proteinase inhibitor- } \\
\text { like gene (win3.12) }\end{array}$ & win3.12T promoter & $\begin{array}{l}\text { Hybrid poplar (Populus } \\
\text { trichocarpa } \times \text { Populus } \\
\text { deltoides) }\end{array}$ & F. solani & GUS & $\begin{array}{l}\text { Yevtushenko et al. } \\
\text { (2004) }\end{array}$ \\
\hline $\begin{array}{l}\text { calmodulin isoform-4 } \\
\text { gene (GmCaM-4) }\end{array}$ & GmCaM-4 promoter & G. $\max$ & $\begin{array}{l}\text { Pseudomonas syringae } \\
\text { pv. Tabaci }\end{array}$ & GUS & Park et al. (2009) \\
\hline $\begin{array}{l}\text { acid-O- } \\
\text { methyltransferase of } \\
\text { class II gene (COMTII) }\end{array}$ & СОMTII promoter & N. tabacum & $\begin{array}{l}\text { TMV, Phytophthora } \\
\text { parasitica var. } \\
\text { nicotianae }\end{array}$ & GUS & Toquin et al. (2003) \\
\hline CAPIP2 gene & CAPIP2 promoter & Capsicum annuum & P. syringae pv. tabaci & GUS & Lee et al. (2007) \\
\hline
\end{tabular}


Table 3. Continued...

\begin{tabular}{|c|c|c|c|c|c|}
\hline Gene (s) & Promoter (s) & $\begin{array}{c}\text { Source of the } \\
\text { promoter }\end{array}$ & $\begin{array}{l}\text { Insect/Pathogen } \\
\text { responsible for the } \\
\text { induction }\end{array}$ & Reporter gene & Ref. \\
\hline $\begin{array}{l}\text { hypersensitivity } \\
\text { related gene } \\
\text { (hsr203J), sensitivity } \\
\text { related gene (str246C) }\end{array}$ & $\begin{array}{l}\text { hsr203J promoter, } \\
\text { sgd24 promoter }\end{array}$ & N. tabacum & $\begin{array}{l}\text { E. amylovora } \\
\text { (str246C and hsr203J } \\
\text { promoters), P. } \\
\text { syringae pv. tabaci } \\
\text { (str246C promoter), P. } \\
\text { syringae pv. syringae } \\
\text { (str246C and hsr203J } \\
\text { promoters) }\end{array}$ & GUS & Malnoy et al. (2003) \\
\hline $\begin{array}{l}\text { basic B-1,3-glucanase } \\
\text { gene }\end{array}$ & gglb50 promoter & N. tabacum & $\begin{array}{l}\text { TMV, potato virus } \\
\text { Y (PVY), cucumber } \\
\text { mosaic virus (CMV) }\end{array}$ & GUS & Livne et al. (1997) \\
\hline $\begin{array}{l}\text { acidic } 1,3-B \text {-glucanase } \\
\text { gene (gluB) }\end{array}$ & gluB promoter & S. tuberosum & TMV, P. infestans & GUS & Mac et al. (2004) \\
\hline $\begin{array}{l}\text { acidic } B-1,3 \text {-glucanase } \\
\text { gene }(P R-2)\end{array}$ & $P R-2 d$ promoter & N. tabacum & TMV & GUS & Hennig et al. (1993) \\
\hline $\begin{array}{l}\text { Pathogenesis-related } \\
\text { protein of group } 1 \\
\text { gene }(P R-1)\end{array}$ & $P R-1 a$ promoter & N. tabacum & TMV & GUS & Strompen et al. (1998) \\
\hline gf-2.8 germin gene & gf-2.8 promoter & T. aestivum & TMV & GUS & Berna \& Bernier (1999) \\
\hline
\end{tabular}

with $B$. graminis f. sp. hordei and Rhynchosporium secalis demonstrated robust induction of GUS expression in leaves upon infection. In addition, high induction of GUS expression was observed in transgenic wheat plants that were generated through a transient expression system after inoculation with B. graminis f. sp. tritici and hordei (Himmelbach et al., 2010).

The soybean polyphenol oxidase 12 gene (GmPPO12) promoter is strongly induced by the oomycetes $P$. sojae and $P$. capsici. Transient expression assays in Nicotiana benthamiana showed 8.2- and 10.8-fold increase in GUS activity levels upon $P$. capsici infection at 0.5 and $2 \mathrm{~h}$, respectively. Additionally, high GUS activity was demonstrated in stable transgenic soybean hairy roots following $P$. sojae infection (Chai et al., 2013). Likewise, the inducible activity of the poplar Win3.12T promoter (Yevtushenko et al., 2004), A. thaliana PAL1 and PDF1.2 promoters (Mohan et al., 1993; Mauch-Mani \& Slusarenko, 1996), T. aestivum PinA promoter (Evrard et al., 2007), O. sativa OsNAC6 promoter (Nakashima et al., 2007), Solanum tuberosum Prp1 promoter (Hahn and Strittmatter 1994) and S. lycopersicum LEACO1 promoter (Blume \& Grierson, 1997) under fungal infection has also been reported.

Yang et al. (2017a) reported that engineered rice lines expressing the GUS reporter gene under the control of the GRMZM2G174449 promoter isolated from maize, whose gene responds to $R$. solani infection, exhibited a 3 -fold increase in GUS activity in leaves after $8 \mathrm{~h}$ of inoculation with the fungus (Yang et al., 2017a). Another study demonstrated that transgenic soybean plants expressing GFP under the control of soybean chitinase gene promoter in Phakopsora pachyrhizichallenged plants exhibited GFP fluorescence around fungal appressorium 24 and $72 \mathrm{~h}$ post-infection (Cabre et al., 2021).
Genetic constructs harboring the maize proteinase inhibitor and the potato carboxypeptidase inhibitor genes under the control of the wound- and pathogen-inducible Mpi promoter from maize were used to transform rice. Subsequently, evaluation of the transgenic plants indicated increased resistance to the insect-pest $C$. suppressalis and the fungus $M$. oryzae without penalty to the plant phenotype (Quilis et al., 2014). This study exemplifies how inducible promoters hold great potential for the development of insect-pest- and disease-resistant plants.

\section{cis-acting co-incident elements in soybean promoters from genes responsible for broad-spectrum biotic stress conditions: new perspectives for synthetic promoter design}

Gene stacking for broad-spectrum resistance is expected to be applied in the development of transgenic plants to improve the agronomic performance of important crops (Guo 2021). However, despite considerable efforts to identify and characterize new promoters for soybean genetic engineering, the availability of effective inducible promoters is far from satisfactory, and it will be worthwhile to continue exploring such promoters for use not only in plant research, but also in commercial transgenic plants.

To identify putative cis-regulatory elements (CREs) commonly found in soybean gene promoters related to biotic stress, we selected 50 top-list upregulated genes using six transcriptome-wide expression data in which soybean was 
subjected to several pests, including: one virus (Soybean Mosaic Virus - SMV - (Zhang et al., 2019), two caterpillars (H. armigera and Lamprosema indicate - (Wang et al., 2017; Zeng et al., 2017), two fungi (Sclerotinia Sclerotiorum and Fusarium oxysporum - (Chang et al., 2019; Ranjan et al., 2019), and one nematode (M. javanica) (Beneventi et al., 2013). The gene list and their respective annotations are shown in Supplementary Table S1. The promoter sequence of each biotic stress-related gene was identified and downloaded from the soybean genome (G. max - Wm82.a2.v1), available on Phytozome v13 (https://phytozome-next.jgi.doe.gov/). A motif search was performed by the in silico tool PLACE (https: / / www.dna.affrc.go.jp/PLACE/?action=newplace), taking $2.0 \mathrm{~Kb}$ of regulatory sequences upstream of the predicted Transcription Start Site (TSS). A Venn analysis (http://bioinformatics.psb.ugent.be/webtools/Venn/) was performed with all putative regulatory motifs identified by the PLACE analyses, in order to identify CREs common across to all evaluated promoter sequences. To identify the overrepresented transcription factor (TF) families, considering all 50 soybean promoters, we used the PlantPAN database v3.0 (http://plantpan.itps.ncku.edu.tw/). The list of CREs and respective TFs is presented in Table 4.

We found 22 co-occurring CREs in all the promoters evaluated, including regulatory motifs related to basal or light-regulated expression in plants, such as CAATBOX1 (5'CAAT-3'), CCAATBOX1 (5'-CCAAT-3'), GATABOX (5'-GATA3'), IBOX (5'-GATAA-3'), and TATABOX5 (5'-TTATTT-3'). In addition, 15 of the 22 CREs screened in the promoter of the 50 biotic stress-related soybean genes were linked to tissue-specific activity and several stimuli or stress responses, as phytohormonal responses, dehydration response, or fungal elicitor activation (Table 4).

Interestingly, a recent study using 13 genes acting as a protein phosphatase 2A (PP2A)-related hub in A. thaliana, co-expressed under several abiotic stress conditions (cold,

Table 4. Relevant cis-elements commonly present in the promoter sequences of 50 biotic stress-related genes in soybean.

\begin{tabular}{|c|c|c|c|c|}
\hline Motif name & Consensus sequence & TF family & Activity & References \\
\hline ARR1AT & NGATT & ARR1 & Cytokinin response & $\begin{array}{l}\text { Sakai et al. (2000) } \\
\text { Ross et al. (2004) }\end{array}$ \\
\hline CACTFTPPCA 1 & YACT & - & Mesophyll specific & $\begin{array}{l}\text { Gowik et al. (2004) } \\
\text { Wang et al. (2015) }\end{array}$ \\
\hline DOFCOREZM & AAAG & Dof & $\begin{array}{l}\text { Carbon metabolism } \\
\text { and stress responses }\end{array}$ & Yanagisawa (2000) \\
\hline TAAAGSTKST1 & TAAAG & Dof & Guard-cell specific & Plesch et al. (2001) \\
\hline EBOXBNNAPA & CANNTG & $\mathrm{bHLH} / \mathrm{MYB}$ & Seed-specific & $\begin{array}{l}\text { Stålberg et al. (1996) } \\
\text { Hartmann et al. (2005) }\end{array}$ \\
\hline GT1CONSENSUS & GRWAAW & GT1-like & $\begin{array}{l}\text { Seed-specific, SA- and } \\
\text { light-responses }\end{array}$ & $\begin{array}{l}\text { Terzaghi \& Cashmore } \\
\text { (1995) } \\
\text { Buchel et al. (1999) }\end{array}$ \\
\hline GT1GMSCAM4 & GAAAAA & GT1-like & $\begin{array}{l}\text { Fungal-elicitors and } \\
\text { salt responses }\end{array}$ & Park et al. (2004) \\
\hline GTGANTG10 & GTGA & - & Pollen-specific & $\begin{array}{l}\text { Rogers et al. (2001) } \\
\text { Bate \& Twell (1998) }\end{array}$ \\
\hline POLLEN1LELAT52 & AGAAA & - & Pollen-specific & Filichkin et al. (2004) \\
\hline \multirow[t]{2}{*}{ MYCCONSENSUSAT } & CANNTG & bHLH & $\begin{array}{l}\text { Dehydration and } \mathrm{ABA} \\
\text { response }\end{array}$ & Abe et al. (2003) \\
\hline & ATATT & - & Root-specific & $\begin{array}{l}\text { Elmayan \& Tepfer } \\
\text { (1995) }\end{array}$ \\
\hline WBOXATNPR1 & TTGAC & WRKY & $\begin{array}{l}\text { Salicylic acid response } \\
\text { and disease resistance }\end{array}$ & Yu et al. (2001) \\
\hline WBOXHVISO1 & TGACT & WRKY & Sugar metabolism & Sun et al. (2003) \\
\hline WBOXNTERF3 & TGACY & WRKY & Wounding response & Nishiuchi et al. (2004) \\
\hline WRKY71OS & TGAC & WRKY & $\begin{array}{l}\text { Pathogenesis-related } \\
\text { and GA responses }\end{array}$ & Zhang et al. (2004) \\
\hline
\end{tabular}

This list does not include CREs involved in basal expression or light-regulated responses. $\left({ }^{*}\right) \mathrm{R}=\mathrm{G}$ or $\mathrm{A} ; \mathrm{Y}=\mathrm{T}$ or $\mathrm{C} ; \mathrm{W}=\mathrm{A}$ or $\mathrm{T} ; \mathrm{N}=\mathrm{A}$ or $\mathrm{T}$ or $\mathrm{C}$ or $\mathrm{G}$ 
drought, heat, osmotic, genotoxic, salt, and wounding) identified 16 CREs co-occurring in the promoters of these 13 genes (Khan et al., 2020). A comparative analysis between 16 CREs found in $A$. thaliana, with the 22 CREs screened by our analyses using the promoter sequences of 50 biotic-stress related soybean genes, revealed the co-occurrence of $14 \mathrm{CREs}$ in both datasets, including tissue-specific activity-related motifs (CACTFTPPCA1, TAAAGSTKST1, EBOXBNNAPA, GT1CONSENSUS, GTGANTG10, POLLEN1LELAT52 and ROOTMOTIFTAPOX1), carbon or sugar metabolisms (DOFCOREZM and WBOXHVISO1), phytohormone response (ARR1AT, MYCCONSENSUSAT, and WRKY71OS), biotic stimulus (GT1GMSCAM4, WBOXATNPR1, and WRKY71OS) or abiotic stimulus (DOFCOREZM, MYCCONSENSUSAT, and WBOXNTERF3). Considering the frequency of CREs in each promoter of the 50 biotic stress-related soybean genes and their specific trans-acting TFs, we observed an overrepresentation of regulatory motifs that act as binding sites for specific TF families, such as MYB, DOF, bHLH, and WRKY, as was found for co-expressed Arabidopsis genes (Khan et al., 2020); which may indicate conserved transcriptional regulation and a crosstalk between pathways required for plant responses to multiple stresses. The highest occurrence was observed for WRKY members, the trans-acting factor binding to the W-box cis-regulatory elements. The WRKY TFs are known regulators involved in plant defense responses to pathogens, such as fungi, insects, and nematodes, as well as to abiotic stresses, such as drought, salinity, wounding, chilling and heat (Yu et al., 2001; Bencke-Malato et al., 2014; Yang et al., 2017a; Dhatterwal et al., 2019; Viana et al., 2021).

The identification of trans-acting factors and respective cis-regulatory motifs regulating the spatial and temporal activity of a plant promoter sequence is crucial to construct an effective synthetic promoter. Our data evidenced the co-occurrence of 14 CREs in 50 biotic stress-related soybean promoters, also found in 13 co-expressed gene promoters of stress-responsive Arabidopsis (Khan et al., 2020). Hence, we suggested that the 14 CREs identified in this study could be used to construct synthetic promoters with efficient transcriptional activity.

The basic composition of a synthetic promoter is the core, also known as the minimal promoter region, and the different specific cis-elements, where they will synergistically regulate transgene expression. When designing a synthetic promoter, the focus should be on the architecture, which means choosing different positions, nucleotide sequences, combinations, and amounts of inducible cis-elements (Dey et al., 2015). Typically, these cis-elements are chosen from other known sequences, and precedents in the literature, particularly for biotic stress responses, have reported a considerable number of engineered promoters responsive to different pathogens and pathogenesis-related hormones associated to tissue specificity-associated elements.

Elements such as silencers, insulators, and enhancers, as well as their combined transcription factors, play an important role (Spitz \& Furlong, 2012). Like native promoters, synthetics still require appropriate transcriptional activators and repressors for precise regulation of transgenes (Liu et al., 2013; Petolino \& Davies, 2013). The development of promoter libraries and the use of other computational tools allow the design of different cis-regulatory elements for synthetic promoters and could evolve into an effective way to evaluate and find new regulatory sequences. In practice, synthetic promoters not only consent to engineered gene expression regulation, but also shorten and optimize the length of constructs, facilitating genetic modification of target organisms. Most synthetic plant promoters are a precise combination of well-characterized specific cis-elements and properly interspaced core motifs (Banerjee et al., 2013; Ali \& Kim, 2019; Kummari et al., 2020). Specific CREs related to biotic stresses and/or hormones already employed in synthetic promoters are summarized in Table 5 .

Naturally, given the functional and structural conservation of plant TFs, coupled with predictive bioinformatics algorithms (upon cis-elements conservation and distribution in endogenous promoters), and wide data from gene expression variation in soybean, it is possible to create an integrated omics pipeline to design genetic constructs precisely focused on controlling specific pests.

\section{Commercial and patent-protected plant pro- moters}

Ongoing efforts to explore plant promoters for biotechnology applications have promising implications for developing optimized crops with stable yield and profitable production. The vast knowledge accumulated on promoter regulation, as outlined above, paves the way for precise control of transgene expression in genetically modified (GM) crops, allowing the minimization of undesired effects and the exploitation of new traits to be engineered. Furthermore, the possibility to control transgene expression spatially and temporally can have a notable impact on food biosecurity, since transgene expression can be directed to inedible plant tissues and towards the development of environmentally friendly GM crops with less environmental impact, by aiming to improve insect-pest and disease resistance and reduce the use of chemical defenses.

The potential role of inducible promoters in these challenges is highlighted not only by the growing number of scientific publications, but also by the number of patent applications. A search for patent applications on the World Intellectual Property Organization (WIPO) PatentScope database from 2011 to April 2021, using different combinations of keywords and logical operators adopted, are presented in Supplementary Table S2. This search disclosed 2,347 patent applications related to constitutive promoters in plants, all filed by biotechnology companies in 18 countries (Figure 2A). A similar search for plant promoters induced by biotic stresses revealed 511 patent applications, most of them filed by biotechnology companies, with some contributions from universities, in 11 countries (Figure 2B). Despite the continuous tendency toward the search for novel plant promoters, the scenario of commercial transgenic crops available worldwide seems to go in the opposite direction.

We searched for plant promoters used in commercial GM varieties of cotton and soybean, considered as the two major GM eudicot crops grown worldwide, listed in GM Approval Database of International Service for the Acquisition of Agri-biotech Applications (ISAAA) (https://www.isaaa. 
Table 5. CREs employed in synthetic plant promoters responsible for different biotic stresses and hormones related.

\begin{tabular}{|c|c|c|}
\hline Nature of the promoter & CRES & Reference \\
\hline \multirow[t]{12}{*}{ Pathogen-inducible } & W- box $((\mathrm{T}) \mathrm{TGAC}(\mathrm{C} / \mathrm{T}))$ & Rushton et al. (2002) \\
\hline & D- box (GGAACC) & Shokouhifar et al. (2011) \\
\hline & GCC box (AGCCGCC) & \\
\hline & JERE(AGACCGCC) & \\
\hline & DRE (TACCGACAT) & \\
\hline & Box S (AGCCACC) & \\
\hline & Gst-1 box ( $\mathrm{S}$ and $\mathrm{W}$ boxes) & \\
\hline & $\begin{array}{c}\text { PR1-motif (ACGTCATAGATGTGGCGGCA } \\
\text { TATATTCTTCAGGACTTTTC) }\end{array}$ & $\begin{array}{l}\text { Mazarei et al. (2008) } \\
\text { Liu et al. (2011) }\end{array}$ \\
\hline & SARE (TTCGACCTCC) & \\
\hline & JAR (TTCGACCTCC and ACGTG) & \\
\hline & ERE (AGCCGCC) & \\
\hline & $\begin{array}{c}\text { UTP boxes (ATAGAAGAAGAGACCC } \\
\text { consensus) }\end{array}$ & Römer et al. (2009) \\
\hline SA inducible & TGACG motif of $F$-Sgt promoter & Kumar et al. (2012) \\
\hline $\begin{array}{l}\text { Wounding-, JA, and } \\
\text { leaf senescence-inducible }\end{array}$ & $\begin{array}{c}\text { JASE1 (CGTCAATGAA) and JASE2 } \\
\text { (CATACGTCGTCAA) }\end{array}$ & Xie et al. (2001) \\
\hline$p$-coumaric acid (4-CA) & $\begin{array}{l}\text { H-box (CCTACC }(N) 7 C T) \text { and the G-box } \\
(\text { CACGTG) }\end{array}$ & Loake et al. (1992) \\
\hline SA/ABA inducible & ACGT - Pmec minimal promoter & Mehrotra \& Mehrotra (2010) \\
\hline
\end{tabular}
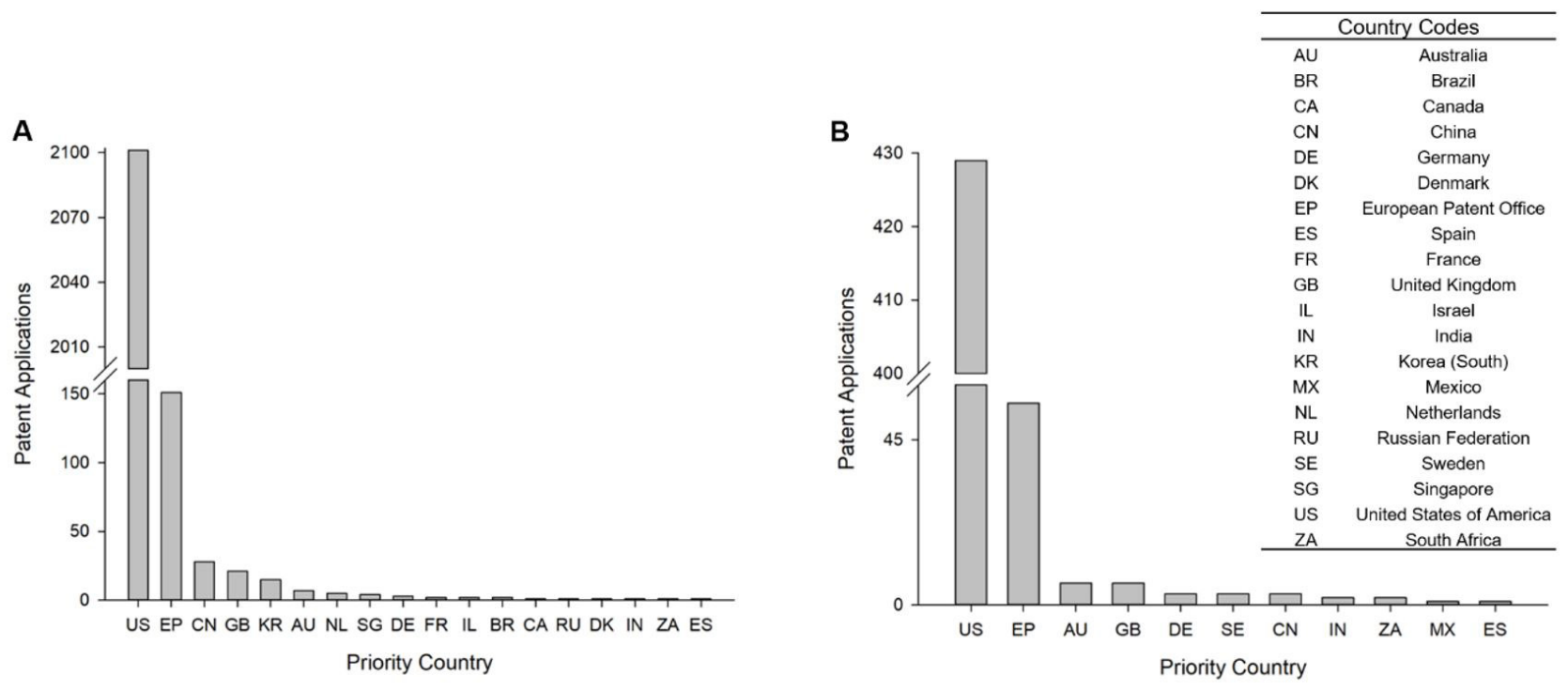

Figure 2. Distribution of patent applications by 1st priority country filed for plant promoters according to WIPO Patentscope, from 2011 to 2021. (A) Data on constitutive plant promoters; (B) Regulated promoters in plants induced by biotic stress.

org/) and in the Biosafety Clearing-House $(\mathrm{BCH})$ database of Living Modified Organisms (LMOs) (http://bch.cbd.int/) (Figure 3). Most of the identified promoters are used for strong constitutive transgene expression, with the exception of seed-specific promoters of the B-conglycinin a' subunit and Kunitz trypsin inhibitor (KTi3) genes of soybean, and 


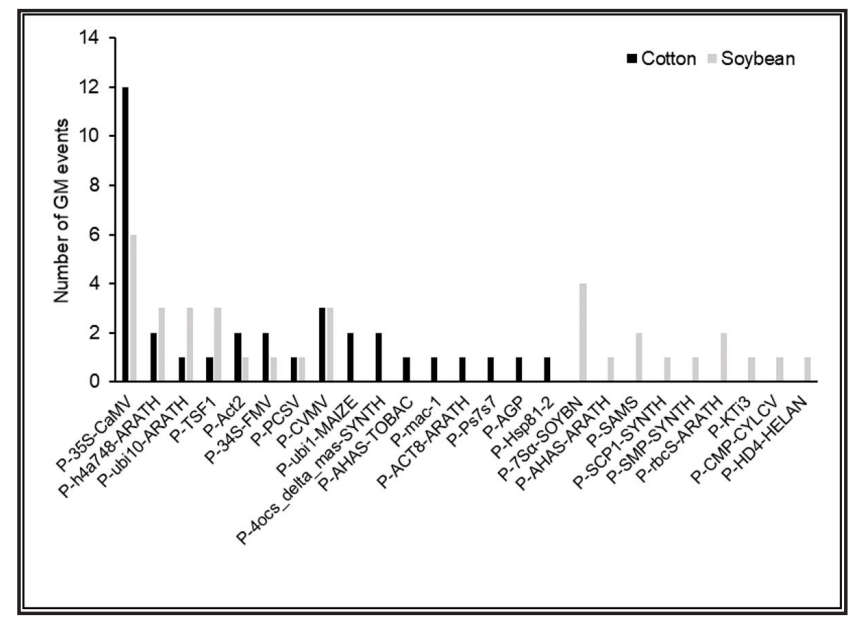

Figure 3. Promoters applied for the development of commercially approved GM soybean and cotton crops listed in the GM Approval Database of the International Service for the Acquisition of Agri-biotech Applications (ISAAA) and in the Biosafety Clearing-House (BCH) database of Living Modified Organisms (LMOs). $P$-35S-CaMV, cauliflower mosaic virus 35 S promoter; $P$ - $h 4 a 748$ ARATH, Arabidopsis thaliana histone $\mathrm{H} 4$ gene promoter; $P$-ubi10ARATH, A. thaliana polyubiquitin10 gene promoter; $P$-TSF1, A. thaliana elongation factor EF-1a gene promoter; P-Act2, A. thaliana actin 2 gene promoter; $P$-34S-FMV, figwort mosaic virus 34 S promoter; $P$-PCSV, peanut chlorotic streak virus promoter; P-CVMV, cassava vein mosaic virus promoter; $P$-ubi1-MAIZE, Zea mays ubiquitin1 gene promoter; $P$-4ocs_delta_mas-SYNTH, 4ocs $\triangle$ Mas2' synthetic promoter; P-AHAS-TOBAC, N. tabacum acetohydroxy acid synthase gene promoter; $P$-mac-1, mac-1 synthetic promoter; $P$-ACT8-ARATH, A. thaliana actin 8 gene promoter; $P$-Ps7s7, subterranean clover stunt virus promoter; $P$-AGP, G. hirsutum a-globulin B gene promoter; P-Hsp81-2, A. thaliana heat shock protein 81-2 gene promoter; $P$-7Sa-SOYBN, $G$. max a' subunit of B-conglycinin gene promoter; $P$-AHAS$A R A T H, A$. thaliana acetohydroxy acid synthase gene promoter; P-SAMS, G. max S-adenosyl-L-methionine synthetase gene promoter; P-SCP1-SYNTH, SCP1 synthetic promoter, P-SMP-SYNTH, synthetic minimal plant promoter; P-rbcS-ARATH, A. thaliana ribulose-1,5-bisphosphate carboxylase small subunit (rbcS) gene promoter; P-KTi3, G. max Kunitz trypsin inhibitor gene promoter; $P$-CMP-CYLCV, Cestrum yellow leaf curling virus promoter; P-HD4-HELAN, Helianthus annuus homeodomain-leucine zipper 4 gene promoter. It was considered promoters driven transgenes related to major crop traits. Promoters controlling reporter or selection markers genes and stacked GM events were not considered. Promoters' designation was considered according to the patent register.

the a-globulin B gene of cotton (Jofuku \& Goldberg, 1989; Fujiwara \& Beachy, 1994; Sunilkumar et al., 2002). There is a predominance of the use of plant virus promoters to maximize gene expression, such as $p C a M V 35 S$, figwort mosaic virus (FMV), cassava vein mosaic virus promoters, among others. These promoters are sometimes combined with other viral elements, like the 5' leader sequences of tobacco etch virus (TEV) and tobacco mosaic virus (Supplementary Table S3).

In some cases, plant virus promoters are joined to the 5 ' elements of plant genes, as in the combination of the pCaMV35S promoter with the 5' UTR and transit peptide of Petunia hybrida chlorophyll a/b-binding protein in GM GHB119 cotton event (Bayer CropScience) or with the 5' UTR of $P$. hybrida HSP 70 gene in MON88701 and Bollgard IITM Monsanto cotton events. The 5' UTR of the 0 . sativa tapetum-specific $E 1$ gene was assembled with pCaMV35S and pPs7s7 promoter of subterranean clover stunt virus in T303-3 (Bayer) and T304-40 (BASF) cotton events, respectively.

The synthetic promoters available are modular combinations of plant virus promoters with enhanced activity, except for the P-4ocs_delta_mas-SYNTH, which is a modular combination of mannose synthase gene promoter and octopine synthase gene enhancers from Ti plasmid from Agrobacterium tumefaciens (Ni et al., 1995). pmac-1, for example, is a combination of pCaMV35S and Ti plasmid mannopine synthetase promoters, showing 3 to 15 times expression of a double pCaMV35S (Comai et al., 1990). The plant minimal synthetic promoter ( $P$-SMP-SYNTH), found in the SYHTOH2 soybean event (Syngenta), includes core sequences from the Cestrum yellow leaf curling virus and $p C a M V 35 S$ virus promoters associated with CaMV and FMV 35S enhancers.

Most of the plant promoters regulating transgene expression identified in commercial GM soybean and cotton crops are from well-known constitutive genes, such as those encoding actin, ubiquitin, histone, elongation factor EF-1a, and ribulose-1,5-bisphosphate carboxylase. Some of these promoters were modified with the addition of plant introns, which are used to enhance transgene expression (Laxa, 2017). For example, the A. thaliana histone $\mathrm{H} 4$ gene promoter combined with the intron II of the histone $\mathrm{H} 3$ gene was able to increase gene expression up to 70-fold (Chaubet-Gigot et al., 2001). This modified promoter is present in the Enlist E3 ${ }^{\mathrm{TM}}$ (Dow AgroSciences) and FG72 (Bayer CropScience) commercial GM soybean events and in the GlyTol ${ }^{\mathrm{TM}}$ and GHB811 Bayer CropScience cotton events. Similarly, the maize ubiquitin intron I, which can enhance up to 5-fold the transgene expression guided by the ubiquitin promoter (Pan et al., 2016), was used in the 281-24-236 cotton event (Dow AgroSciences). Plant promoters are also employed in GM crops combined with viral elements, such as FMV and CaMV35S enhancers and TEV 5' leader sequence (Supplementary Table S3). The Actin 8 promoter, for example, was modified by including an upstream pCaMV35S enhancer as well as the actin 8 5' UTR and intron sequences to drive the 5-enolpyruvylshikimate3-phosphate synthase gene in Monsanto Roundup Ready ${ }^{\mathrm{TM}}$ Flex ${ }^{\top M} \mathrm{GM}$ cotton event.

The higher number of patents related to constitutive promoters, which is a current trend, and the predominance of GM crops with strong constitutive promoters reflect the GM traits explored to date. The majority of GM soybean and cotton events were developed for insect resistance through the high expression of $B$. thurigiensis Cry genes or tolerance to glyphosate and glufosinate-ammonium herbicides by expressing high levels of 5-enolpyruvylshikimate-3-phosphate synthase and phosphinothricin $N$-acetyltransferase genes, respectively. Few GM events show improved oilseed quality, such as the altered fatty acid composition in soybean and reduced gossypol levels in cotton, for which seed-specific promoters were applied.

Another issue to analyze is the cost and time for the development and release of a GM event. The entire process, including event selection, large-scale testing in multiple 
locations, regulatory dossier, and registration affairs, can take about 10 years with an estimated cost of over US\$ 2 billion (Schiek et al., 2016). This means that new trends take a decade to be brought into a biotechnology product. Also, the high costs of releasing a GM crop, exploring new traits, sometimes with low economic value products, are a barrier for non-profit institutions, even though these institutions are hubs where most of the basic exploratory research is performed.

Considering all the accumulated information on plant stress-inducible genes, supported by high-throughput genome analyses, and the molecular tools for promoter cis-acting elements identification, some questions can be raised. Why are research advances on this topic not widely applied to the development of GM crops? Why is the availability of effective inducible promoters far from satisfactory? The establishment of a list of effective promoters for the introgression of specific traits in GM plants depends strongly on the knowledge of the reactivity of certain plant genes, their kinetics and their mode of expression in multiple situations. Thus, the first step in genetic engineering relies on the identification of genes whose expression profiles converge on the characteristics that need to be explored in GM plants and whose promoters can be employed in expression cassette design. Functional characterization of genes in crop plants remains featureless, imposing barriers to the wide availability of inducible promoters, which justifies the hallmarked abundance of GM (commercial or not) plants with transgenes driven by viral promoters. In summary, the more gene function is known, the more inducible promoters will be available for molecular plant breeding.

\section{Final remarks}

Considerable success has been achieved in the last few decades on promoters' characterization and engineering. They have a direct impact on the molecular selection of plants and promote the release of new crops. However, several issues related to transgene expression must be addressed to avoid compromising crop yield and biosafety. Viral constitutive promoters remain widely employed to drive the expression of genes of interest and have provided high transcripts and protein levels in a large number of plant species. Most patent-protected transgenic crops have transgene expression driven by viral constitutive promoters. Nonetheless, the indiscriminate expression of transgenes in engineered plants can impose energy costs that affect plant fitness. With the advancements in the genome and transcriptome-wide analyses, novel monocot and eudicot constitutive promoters have been characterized and introduced into model and crop plants, demonstrating a new way to partially overcome the typical complications of using viral promoters. Notably, constitutive plant promoters do not interplay a fine-tuned control of gene expression and, for specific conditions, still, impair plant yield. Moreover, most of them do not exhibit significant expression in specific plant tissues and do not represent the best choice for improving specific traits, such as insect-pest and disease controls.
In this light, we reviewed the progress made over the past 10 years on characterizing inducible plant promoters, primarily those involved in biotic stress responses. Several promoters have been described as responsible for insect-pest attack and applied in constructs encompassing Cry-based toxins, followed by other promoters responsible for certain nematodes and fungi species, but more information is still needed for other pests. A promising alternative is the use of synthetic promoters harboring cis-acting elements already characterized in a broad spectrum of promoters from genes induced by multiple biotic stresses. By revisiting transcriptome data from soybean subjected to multiple biotic stresses, we have pointed out several co-incident conserved cis-elements in promoters of genes responsible to virus, insect, fungi, and phytonematodes, providing a new set of elements suitable for promoter design, consistent with elements already described in previous reports in the literature. Our analyses reinforce the need to study the function of genes, their expression profile and the regulatory networks to which they belong, as an efficient way to obtain basic data for biotechnological selection.

Finally, genome editing has opened a new era in the design of synthetic promoters. The CRISPR activation and CRISPR interference techniques, referred to as CRISPRa/ CRISPRi, occupy an unexplored place in the field of gene expression control dispensing with the need for ciselement engineering. In this case, by using a dCas9-based strategy, a sgRNA molecule is able to direct transcriptional modulator complexes to a region of a specific promoter, up- or down-regulating target genes (Lowder et al., 2018; Roca Paixão et al., 2019; Melo et al., 2020). Collectively, knowledge over different promoters in different plant systems coupled with the precise design of synthetic promoters and CRISPRa/CRISPRi transcriptional modulator complexes can effectively modernize plant genetic engineering, fueling the biotechnological goal of successfully expressing multiple transgenes in a single superior crop with higher productivity and multiple desirable traits.

\section{Conflict of interests}

The authors declare that this work was conceived in absence of interest conflicts.

\section{References}

Abe, H., Urao, T., Ito, T., Seki, M., Shinozaki, K., \& YamaguchiShinozaki, K. (2003). Arabidopsis AtMYC2 (bHLH) and AtMYB2 (MYB) function as transcriptional activators in abscisic acid signaling. The Plant Cell, 15(1), 63-78. http://dx.doi.org/10.1105/ tpc.006130. PMid:12509522.

Ali, S., \& Kim, W.-C. (2019). A fruitful decade using synthetic promoters in the improvement of transgenic plants. Frontiers in Plant Science, 10, 1433. http://dx.doi.org/10.3389/ fpls.2019.01433. PMid:31737027.

Althoff, F., Kopischke, S., Zobell, O., Ide, K., Ishizaki, K., Kohchi, T., \& Zachgo, S. (2014). Comparison of the MpEF1a and CaMV35S promoters for application in Marchantia polymorpha 
overexpression studies. Transgenic Research, 23(2), 235-244. http://dx.doi.org/10.1007/s11248-013-9746-z. PMid:24036909.

Bae, S.-H., Han, H. W. \& Moon, J. (2015). Functional analysis of the molecular interactions of TATA box-containing genes and essential genes. PLoS One, 10(3), e0120848. http://dx.doi.org/10.1371/ journal.pone.0120848. PMid:25789484.

Banerjee, J., Sahoo, D. K., Dey, N., Houtz, R. L., \& Maiti, I. B. (2013). An intergenic region shared by At4g35985 and At4g35987 in Arabidopsis thaliana is a tissue specific and stress inducible bidirectional promoter analyzed in transgenic Arabidopsis and tobacco plants. PLoS One, 8(11), e79622. http://dx.doi. org/10.1371/journal. pone.0079622. PMid:24260266.

Baruah, I., Baldodiya, G. M., Sahu, J., \& Baruah, G. (2020). Dissecting the role of promoters of pathogen-sensitive genes in plant defense. Current Genomics, 21(7), 491-503. http://dx.doi.org/10.2174/ 1389202921999200727213500 . PMid:33214765.

Basso, M. F., Lourenço-Tessutti, I. T., Busanello, C., Pinto, C. E. M., de Oliveira, F. E., Ribeiro, T. P., Almeida-Engler, J., Oliveira, A. C., Morgante, C. V., Alves-Ferreira, M., \& Grossi-de-Sa, M. F. (2020). Insights obtained using different modules of the cotton uceA1.7 promoter. Planta, 251(2), 56. http://dx.doi.org/10.1007/ s00425-020-03348-8. PMid:32006110.

Basu, S., Roychoudhury, A., \& Sengupta, D. N. (2014). Deciphering the role of various cis-acting regulatory elements in controlling SamDC gene expression in rice. Plant Signaling \& Behavior, 9(1), e28391. http://dx.doi.org/10.4161/psb.28391. PMid:24603050.

Bate, N., \& Twell, D. (1998). Functional architecture of a late pollen promoter: Pollen-specific transcription is developmentally regulated by multiple stage-specific and co-dependent activator elements. Plant Molecular Biology, 37(5), 859-869. http: //dx.doi. org/10.1023/A:1006095023050. PMid:9678581.

Bencke-Malato, M., Cabreira, C., Wiebke-Strohm, B., Bücker-Neto, L., Mancini, E., Osorio, M. B., Homrich, M. S., Turchetto-Zolet, A. C., De Carvalho, M. C., Stolf, R., Weber, R. L., Westergaard, G., Castagnaro, A. P., Abdelnoor, R. V., Marcelino-Guimarães, F. C., Margis-Pinheiro, M., \& Bodanese-Zanettini, M. H. (2014). Genome-wide annotation of the soybean WRKY family and functional characterization of genes involved in response to Phakopsora pachyrhizi infection. BMC Plant Biology, 14(1), 236. http://dx.doi.org/10.1186/s12870-014-0236-0. PMid:25201117.

Beneventi, M. A., Silva Junior, O. B., Sá, M. E. L., Firmino, A. A. P., Amorim, R. M. S., Albuquerque, É. V. S., Silva, M. C. M., Silva, J. P., Campos, M. A., Lopes, M. J. C., Togawa, R. C., Pappas Junior, G. J., \& Grossi-de-Sa, M. F. (2013). Transcription profile of soybeanroot-knot nematode interaction reveals a key role of phythormones in the resistance reaction. BMC Genomics, 14(1), 322. http:// dx.doi.org/10.1186/1471-2164-14-322. PMid:23663436.

Berna, A., \& Bernier, F. (1999). Regulation by biotic and abiotic stress of a wheat germin gene encoding oxalate oxidase, a $\mathrm{H} 2 \mathrm{O} 2$ producing enzyme. Plant Molecular Biology, 39(3), 539-549. http://dx.doi.org/10.1023/A:1006123432157. PMid:10092181.

Bhattacharyya, J., Chowdhury, A. H., Ray, S., Jha, J. K., Das, S., Gayen, S., Chakraborty, A., Mitra, J., Maiti, M. K., Basu, A., \& Sen, S. K. (2012). Native polyubiquitin promoter of rice provides increased constitutive expression in stable transgenic rice plants. Plant Cell Reports, 31(2), 271-279. http://dx.doi.org/10.1007/ s00299-011-1161-4. PMid:21996937.

Bitas, R., Szafran, K., Hnatuszko-Konka, K., \& Kononowicz, A. K. (2016). Cis-regulatory elements used to control gene expression in plants. Plant Cell, Tissue and Organ Culture, 127(2), 269-287. http://dx.doi.org/10.1007/s11240-016-1057-7.

Blume, B., \& Grierson, D. (1997). Expression of ACC oxidase promoter-GUS fusions in tomato and Nicotiana plumbaginifolia regulated by developmental and environmental stimuli. The Plant Journal, 12(4), 731-746. http://dx.doi.org/10.1046/j.1365313X.1997.12040731.x. PMid:9375389.

Boni, R., Chauhan, H., Hensel, G., Roulin, A., Sucher, J., Kumlehn, J., Brunner, S., Krattinger, S. G., \& Keller, B. (2018). Pathogeninducible Ta-Lr34res expression in heterologous barley confers disease resistance without negative pleiotropic effects. Plant Biotechnology Journal, 16(1), 245-253. http://dx.doi. org/10.1111/pbi.12765. PMid:28561994.

Buchel, A. S., Brederode, F. T., Bol, J. F., \& Linthorst, H. J. (1999). Mutation of GT-1 binding sites in the Pr-1A promoter influences the level of inducible gene expression in vivo. Plant Molecular Biology, 40(3), 387-396. http://dx.doi.org/10.1023/A:1006144505121. PMid:10437823.

Cabre, L., Peyrard, S., Sirven, C., Gilles, L., Pelissier, B., Ducerf, S., \& Poussereau, N. (2021). Identification and characterization of a new soybean promoter induced by Phakopsora pachyrhizi, the causal agent of Asian soybean rust. BMC Biotechnology, 21(1), 27. http://dx.doi.org/10.1186/s12896-021-00684-9. PMid:33765998.

Cazzonelli, C. I., McCallum, E. J., Lee, R., \& Botella, J. R. (2005). Characterization of a strong, constitutive mung bean (Vigna radiata $\mathrm{L}$.) promoter with a complex mode of regulation in planta. Transgenic Research, 14(6), 941-967. http://dx.doi.org/10.1007/ s11248-005-2539-2. PMid:16315097.

Chai, C., Lin, Y., Shen, D., Wu, Y., Li, H., \& Dou, D. (2013). Identification and functional characterization of the soybean GmaPPO12 promoter conferring Phytophthora sojae induced expression. PLoS One, 8(6), e67670. http://dx.doi.org/10.1371/ journal.pone.0067670. PMid:23840763.

Chang, C., Tian, L., Ma, L., Li, W., Nasir, F., Li, X., Tran, L. P., \& Tian, C. (2019). Differential responses of molecular mechanisms and physiochemical characters in wild and cultivated soybeans against invasion by the pathogenic Fusarium oxysporum Schltdl. Physiologia Plantarum, 166(4), 1008-1025. http://dx.doi. org/10.1111/ppl.12870. PMid:30430602.

Chaubet-Gigot, N., Kapros, T., Flenet, M., Kahn, K., Gigot, C., \& Waterborg, J. H. (2001). Tissue-dependent enhancement of transgene expression by introns of replacement histone $\mathrm{H} 3$ genes of Arabidopsis. Plant Molecular Biology, 45(1), 17-30. http:// dx.doi.org/10.1023/A:1006487023926. PMid:11247603.

Chen, Z., Wang, J., Ye, M.-X., Li, H., Ji, L.-X., Li, Y., Cui, D. Q., Liu, J. M., \& An, X. M. (2013). A novel moderate constitutive promoter derived from poplar (Populus tomentosa Carrière). International Journal of Molecular Sciences, 14(3), 6187-6204. http://dx.doi. org/10.3390/ijms14036187. PMid:23507754.

Chiera, J. M., Bouchard, R. A., Dorsey, S. L., Park, E., BuenrostroNava, M. T., Ling, P. P., \& Finer, J. J. (2007). Isolation of two highly active soybean (Glycine max (L.) Merr.) promoters and their characterization using a new automated image collection and analysis system. Plant Cell Reports, 26(9), 1501-1509. http: // dx.doi.org/10.1007/s00299-007-0359-y. PMid:17503049.

Christensen, A. H., Sharrock, R. A., \& Quail, P. H. (1992). Maize polyubiquitin genes: structure, thermal perturbation of expression and transcript splicing, and promoter activity following transfer to protoplasts by electroporation. Plant Molecular Biology, 18(4), 675-689. http://dx.doi.org/10.1007/BF00020010. PMid:1313711.

Comai, L., Moran, P., \& Maslyar, D. (1990). Novel and useful properties of a chimeric plant promoter combining CaMV $35 \mathrm{~S}$ and MAS elements. Plant Molecular Biology, 15(3), 373-381. http:// dx.doi.org/10.1007/BF00019155. PMid:2103458.

Corte, L. E.-D., Mendes, B. M. J., Filho, F. A. A. M., Grosser, J. W., \& Dutt, M. (2020). Functional characterization of fulllength and $5^{\prime}$ deletion fragments of Citrus sinensis-derived constitutive promoters in Nicotiana benthamiana. In Vitro Cellular \& Developmental Biology, 56(3), 280-289. http: / / dx.doi. org/10.1007/s11627-019-10044-0.

Coussens, G., Aesaert, S., Verelst, W., Demeulenaere, M., De Buck, S., Njuguna, E., Inzé, D., \& Van Lijsebettens, M. (2012). Brachypodium distachyon promoters as efficient building blocks for transgenic research in maize. Journal of Experimental Botany, 63(11), 42634273. http://dx.doi.org/10.1093/jxb/ers113. PMid:22523343.

Cui, L., Feng, K., Wang, M., Wang, M., Deng, P., Song, W., \& Nie, X. (2016). Genome-wide identification, phylogeny and expression analysis of AP2/ERF transcription factors family in 
Brachypodium distachyon. BMC Genomics, 17(1), 636. http:// dx.doi.org/10.1186/s12864-016-2968-8. PMid:27527343.

Datta, K., Vasquez, A., Tu, J., Torrizo, L., Alam, M. F., Oliva, N., Abrigo, E., Khush, G. S., \& Datta, S. K. (1998). Constitutive and tissue-specific differential expression of the $\operatorname{cryl}(A(b)$ gene in transgenic rice plants conferring resistance to rice insect pest. Theoretical and Applied Genetics, 97(1-2), 20-30. http://dx.doi. org/10.1007/s001220050862.

Dey, N., Sarkar, S., Acharya, S., \& Maiti, I. B. (2015). Synthetic promoters in planta. Planta, 242(5), 1077-1094. http://dx.doi. org/10.1007/s00425-015-2377-2. PMid:26250538.

Dhatterwal, P., Basu, S., Mehrotra, S., \& Mehrotra, R. (2019). Genome wide analysis of W-box element in Arabidopsis thaliana reveals TGAC motif with genes down regulated by heat and salinity. Scientific Reports, 9(1), 1681. http://dx.doi.org/10.1038/s41598019-38757-7. PMid:30737427.

Dong, H., Shi, S., Zhang, C., Zhu, S., Li, M., Tan, J., Yu, Y., Lin, L., Jia, S., Wang, X., Wu, Y., \& Liu, Y. (2018). Transcriptomic analysis of genes in soybean in response to Peronospora manshurica infection. BMC Genomics, 19(1), 366. http://dx.doi.org/10.1186/ s12864-018-4741-7. PMid:29776333.

Dubey, N. K., Mishra, D. K., Idris, A., Nigam, D., Singh, P. K., \& Sawant, S. V. (2018). Whitefly and aphid inducible promoters of Arabidopsis thaliana L. Journal of Genetics, 97(1), 109-119. http://dx.doi.org/10.1007/s12041-018-0887-y. PMid:29666330.

Elmayan, T., \& Tepfer, M. (1995). Evaluation in tobacco of the organ specificity and strength of the rolD promoter, domain $A$ of the $35 \mathrm{~S}$ promoter and the 35S2 promoter. Transgenic Research, 4(6), 388-396. http://dx.doi.org/10.1007/BF01973757. PMid:7581519.

Erpen, L., Tavano, E. C. R., Harakava, R., Dutt, M., Grosser, J. W., Piedade, S. M. S., Mendes, B. M. J., \& Mourão Filho, F. A. A. (2018). Isolation, characterization, and evaluation of three Citrus sinensis-derived constitutive gene promoters. Plant Cell Reports, 37(8), 1113-1125. http://dx.doi.org/10.1007/s00299018-2298-1. PMid:29796947.

Escobar, C., Barcala, M., Portillo, M., Almoguera, C., Jordano, J., \& Fenoll, C. (2003). Induction of the Hahsp17.7G4 promoter by root-knot nematodes: Involvement of heat-shock elements in promoter activity in giant cells. Molecular Plant-Microbe Interactions, 16(12), 1062-1068. http://dx.doi.org/10.1094/ MPMI.2003.16.12.1062. PMid:14651339.

Escobar, C., De Meutter, J., Aristizábal, F. A., Sanz-Alférez, S., del Campo, F. F., Barthels, N., Van der Eycken, W., Seurinck, J., van Montagu, M., Gheysen, G., \& Fenoll, C. (1999). Isolation of the LEMMI9 gene and promoter analysis during a compatible plantnematode interaction. Molecular Plant-Microbe Interactions, 12(5), 440-449. http://dx.doi.org/10.1094/MPMI.1999.12.5.440. PMid:10226377.

Evrard, A., Meynard, D., Guiderdoni, E., Joudrier, P., \& Gautier, M. -F. (2007). The promoter of the wheat puroindoline-a gene (PinA) exhibits a more complex pattern of activity than that of the PinB gene and is induced by wounding and pathogen attack in rice. Planta, 225(2), 287-300. http://dx.doi.org/10.1007/ s00425-006-0347-4. PMid:16845527.

Fassler, J., Landsman, D., Acharya, A., Moll, J. R., Bonovich, M., \& Vinson, C. (2002). B-ZIP proteins encoded by the Drosophila genome: Evaluation of potential dimerization partners. Genome Research, 12(8), 1190-1200. http://dx.doi.org/10.1101/gr.67902. PMid:12176927.

Feng, C.-Z., Chen, Y., Wang, C., Kong, Y.-H., Wu, W.-H., \& Chen, Y.-F. (2014). Arabidopsis RAV1 transcription factor, phosphorylated by SnRK2 kinases, regulates the expression of $A B / 3, A B I 4$, and $A B I 5$ during seed germination and early seedling development. The Plant Journal, 80(4), 654-668. http://dx.doi.org/10.1111/ tpj.12670. PMid:25231920.

Filichkin, S. A., Leonard, J. M., Monteros, A., Liu, P.-P., \& Nonogaki, H. (2004). A novel endo-beta-mannanase gene in tomato LeMAN5 is associated with anther and pollen development. Plant Physiology,
134(3), 1080-1087. http://dx.doi.org/10.1104/pp.103.035998. PMid: 14976239.

Foster, E., Hattori, J., Labbé, H., Ouellet, T., Fobert, P. R., James, L. E., Iyer, V. N., \& Miki, B. L. (1999). A tobacco cryptic constitutive promoter, tCUP, revealed by T-DNA tagging. Plant Molecular Biology, 41(1), 45-55. http://dx.doi. org/10.1023/A:1006229501860. PMid:10561067.

Freitas, E. O., Melo, B. P., Lourenço-Tessutti, I. T., Arraes, F. B. M., Amorim, R. M., Lisei-de-Sá, M. E., Costa, J. A., Leite, A. G. B., Faheem, M., Ferreira, M. A., Morgante, C. V., Fontes, E. P. B., \& Grossi-de-Sa, M. F. (2019). Identification and characterization of the GmRD26 soybean promoter in response to abiotic stresses: Potential tool for biotechnological application. BMC Biotechnology, 19(1), 79. http://dx.doi.org/10.1186/s12896-019-0561-3. PMid:31747926.

Fujiwara, T., \& Beachy, R. N. (1994). Tissue-specific and temporal regulation of a beta-conglycinin gene: roles of the RY repeat and other cis-acting elements. Plant Molecular Biology, 24(2), 261-272. http://dx.doi.org/10.1007/BF00020166. PMid:8111031.

Godard, K.-A., Byun-McKay, A., Levasseur, C., Plant, A., Séguin, A., \& Bohlmann, J. (2007). Testing of a heterologous, wound- and insect-inducible promoter for functional genomics studies in conifer defense. Plant Cell Reports, 26(12), 2083-2090. http:// dx.doi.org/10.1007/s00299-007-0417-5. PMid:17671786.

Gowik, U., Burscheidt, J., Akyildiz, M., Schlue, U., Koczor, M., Streubel, M., \& Westhoff, P. (2004). cis-Regulatory elements for mesophyll-specific gene expression in the C4 plant Flaveria trinervia, the promoter of the C4 phosphoenolpyruvate carboxylase gene. The Plant Cell, 16(5), 1077-1090. http:// dx.doi.org/10.1105/tpc.019729. PMid:15100398.

Grossi-de-Sa, M. F., Guimarães, L. M., Batista, J. A. N., Viana, A. A. B., Fragoso, R. R., \& Silva, M. C. M. (2013). Compositions and methods for modifying gene expression using the promoter of ubiquitin conjugating protein coding gene of soybean plants. United States Patent and Trademark Office US9012720B2.

Gu, C., Guo, Z.-H., Hao, P.-P., Wang, G.-M., Jin, Z.-M., \& Zhang, S.-L. (2017). Multiple regulatory roles of AP2/ERF transcription factor in angiosperm. Botanical Studies, 58(1), 6. http://dx.doi. org/10.1186/s40529-016-0159-1. PMid:28510189.

Guo, Y. (2021). Gene stacking for broad-spectrum resistance. Nature Food, 2(2), 75. http://dx.doi.org/10.1038/s43016-021-00237-5.

Gurr, S. J., \& Rushton, P. J. (2005). Engineering plants with increased disease resistance: How are we going to express it? Trends in Biotechnology, 23(6), 283-290. http://dx.doi.org/10.1016/j. tibtech.2005.04.009. PMid:15922080.

Hahn, K., \& Strittmatter, G. (1994). Pathogen-defence gene prp1-1 from potato encodes an auxin-responsive glutathione S-transferase. European Journal of Biochemistry, 226(2), 619626. http://dx.doi.org/10.1111/j.1432-1033.1994.tb20088.x. PMid:8001577.

Han, Y.-J., Kim, Y.-M., Hwang, O.-J., \& Kim, J.-I. (2015). Characterization of a small constitutive promoter from Arabidopsis translationally controlled tumor protein (ATTCTP) gene for plant transformation. Plant Cell Reports, 34(2), 265-275. http://dx.doi. org/10.1007/s00299-014-1705-5. PMid:25410250.

Hansen, E., Harper, G., \& McPherson, M. J. (1996). Differential expression patterns of the wound-inducible transgenewun1uidAin potato roots following infection with either cyst or root knot nematodes. Physiological and Molecular Plant Pathology, 48(3), 161-170. http://dx.doi.org/10.1006/pmpp.1996.0014.

Hartmann, U., Sagasser, M., Mehrtens, F., Stracke, R., \& Weisshaar, B. (2005). Differential combinatorial interactions of cis-acting elements recognized by R2R3-MYB, BZIP, and BHLH factors control light-responsive and tissue-specific activation of phenylpropanoid biosynthesis genes. Plant Molecular Biology, 57(2), 155-171. http://dx.doi.org/10.1007/s11103-004-6910-0. PMid:15821875.

Hennig, J., Dewey, R. E., Cutt, J. R., \& Klessig, D. F. (1993). Pathogen, salicylic acid and developmental dependent expression of a beta1,3-glucanase/GUS gene fusion in transgenic tobacco plants. The 
Plant Journal, 4(3), 481-493. http://dx.doi.org/10.1046/j.1365313X.1993.04030481.x. PMid:8220491.

Hernandez-Garcia, C. M., \& Finer, J. J. (2014). Identification and validation of promoters and cis-acting regulatory elements. Plant Science, 217-218, 109-119. http://dx.doi.org/10.1016/j. plantsci.2013.12.007. PMid:24467902.

Hernandez-Garcia, C. M., Martinelli, A. P., Bouchard, R. A., \& Finer, J. J. (2009). A soybean (Glycine max) polyubiquitin promoter gives strong constitutive expression in transgenic soybean. Plant Cell Reports, 28(5), 837-849. http: / /dx.doi.org/10.1007/s00299-0090681-7. PMid:19229538.

Hetzel, J., Duttke, S. H., Benner, C., \& Chory, J. (2016). Nascent RNA sequencing reveals distinct features in plant transcription. Proceedings of the National Academy of Sciences of the United States of America, 113(43), 12316-12321. http://dx.doi. org/10.1073/pnas.1603217113. PMid:27729530.

Himmelbach, A., Liu, L., Zierold, U., Altschmied, L., Maucher, H., Beier, F., Müller, D., Hensel, G., Heise, A., Schützendübel, A., Kumlehn, J., \& Schweizer, P. (2010). Promoters of the barley germin-like GER4 gene cluster enable strong transgene expression in response to pathogen attack. The Plant Cell, 22(3), 937-952. http://dx.doi.org/10.1105/tpc.109.067934. PMid:20305123.

Hong, J. K., Suh, E. J., Kwon, S.-J., Lee, S. B., Kim, J. A., Lee, S. I., \& Lee, Y.-H. (2016). Promoter of chrysanthemum actin confers high-level constitutive gene expression in Arabidopsis and chrysanthemum. Scientia Horticulturae, 211, 8-18. http:// dx.doi.org/10.1016/j.scienta.2016.08.006.

Hua, H., Lu, Q., Cai, M., Xu, C., Zhou, D.-X., Li, X., \& Zhang, Q. (2007). Analysis of rice genes induced by striped stemborer (Chilo suppressalis) attack identified a promoter fragment highly specifically responsive to insect feeding. Plant Molecular Biology, 65(4), 519-530. http://dx.doi.org/10.1007/s11103-007-9185-4. PMid: 17522952.

Jang, I.-C., Choi, W.-B., Lee, K.-H., Song, S. I., Nahm, B. H., \& Kim, J.-K. (2002). High-level and ubiquitous expression of the rice cytochrome $c$ gene $0 s C c 1$ and its promoter activity in transgenic plants provides a useful promoter for transgenesis of monocots. Plant Physiology, 129(4), 1473-1481. http://dx.doi.org/10.1104/ pp.002261. PMid:12177461.

Jiang, P., Zhang, K., Ding, Z., He, Q., Li, W., Zhu, S., Cheng, W., Zhang, K., \& Li, K. (2018). Characterization of a strong and constitutive promoter from the Arabidopsis serine carboxypeptidase-like gene AtSCPL30 as a potential tool for crop transgenic breeding. BMC Biotechnology, 18(1), 59. http://dx.doi.org/10.1186/s12896018-0470-x. PMid:30241468.

Jofuku, K. D., \& Goldberg, R. B. (1989). Kunitz trypsin inhibitor genes are differentially expressed during the soybean life cycle and in transformed tobacco plants. The Plant Cell, 1(11), 10791093. http://dx.doi.org/10.1105/tpc.1.11.1079. PMid:2562561.

Kakrana, A., Kumar, A., Satheesh, V., Abdin, M. Z., Subramaniam, K., Bhattacharya, R. C., Srinivasan, R., Sirohi, A., \& Jain, P. K. (2017). Identification, validation and utilization of novel nematoderesponsive root-specific promoters in Arabidopsis for inducing host-delivered RNAi mediated root-knot nematode resistance. in of Plant Science, 8, 2049. http://dx.doi.org/10.3389/ fpls.2017.02049. PMid:29312363.

Kang, T.-J., Kwon, T.-H., Kim, T.-G., Loc, N.-H., \& Yang, M.-S. (2003). Comparing constitutive promoters using CAT activity in transgenic tobacco plants. Molecules and Cells, 16(1), 117-122. PMid:14503855.

Kasuga, M., Miura, S., Shinozaki, K., \& Yamaguchi-Shinozaki, K. (2004). A combination of the Arabidopsis DREB1A gene and stress-inducible rd29A promoter improved drought- and lowtemperature stress tolerance in tobacco by gene transfer. Plant \& Cell Physiology, 45(3), 346-350. http://dx.doi.org/10.1093/ pcp/pch037. PMid:15047884.

Kelly, G., Lugassi, N., Belausov, E., Wolf, D., Khamaisi, B., Brandsma, D., Kottapalli, J., Fidel, L., Ben-Zvi, B., Egbaria, A., Acheampong, A. K., Zheng, C., Or, E., Distelfeld, A., David-Schwartz, R., Carmi,
N., \& Granot, D. (2017). The Solanum tuberosum KST1 partial promoter as a tool for guard cell expression in multiple plant species. Journal of Experimental Botany, 68(11), 2885-2897. http://dx.doi.org/10.1093/jxb/erx159. PMid:28531314.

Khan, Z. H., Agarwal, S., Rai, A., Memaya, M. B., Mehrotra, S., \& Mehrotra, R. (2020). Co-expression network analysis of protein phosphatase 2A (PP2A) genes with stress-responsive genes in Arabidopsis thaliana reveals 13 key regulators. Scientific Reports, 10(1), 21480. http://dx.doi.org/10.1038/s41598-020-77746-z. PMid:33293553.

Koch, K. G., Palmer, N. A., Donze-Reiner, T., Scully, E. D., Seravalli, J., Amundsen, K., Twigg, P., Louis, J., Bradshaw, J. D., Heng-Moss, T. M., \& Sarath, G. (2020). Aphid-responsive defense networks in hybrid switchgrass. Frontiers in Plant Science, 11, 1145. http: // dx.doi.org/10.3389/fpls.2020.01145. PMid:32849703.

Koia, J., Moyle, R., Hendry, C., Lim, L., \& Botella, J. R. (2013). Pineapple translation factor SUI1 and ribosomal protein L36 promoters drive constitutive transgene expression patterns in Arabidopsis thaliana. Plant Molecular Biology, 81(4-5), 327-336. http://dx.doi.org/10.1007/s11103-012-0002-3. PMid:23263857.

Koschmann, J., Machens, F., Becker, M., Niemeyer, J., Schulze, J., Bülow, L., Stahl, D. J., \& Hehl, R. (2012). Integration of bioinformatics and synthetic promoters leads to the discovery of novel elicitor-responsive cis-regulatory sequences in Arabidopsis. Plant Physiology, 160(1), 178-191. http://dx.doi.org/10.1104/ pp.112.198259. PMid:22744985.

Kumar, A., Joshi, I., Kohli, D., Satheesh, V., Abdin, M. Z., Sirohi, A., Srinivasan, R., \& Jain, P. K. (2016). Characterization of root-knot nematode responsive and root-specific promoter containing PIN domain from Arabidopsis thaliana (L.) Heynh. Indian Journal of Genetics and Plant Breeding, 76(1), 75. http://dx.doi. org/10.5958/0975-6906.2016.00011.0.

Kumar, D., Patro, S., Ghosh, J., Das, A., Maiti, I. B., \& Dey, N. (2012). Development of a salicylic acid inducible minimal sub-genomic transcript promoter from Figwort mosaic virus with enhanced root- and leaf-activity using TGACG motif rearrangement. Gene, 503(1), 36-47. http://dx.doi.org/10.1016/j.gene.2012.04.053. PMid:22561698.

Kummari, D., Palakolanu, S. R., Kishor, P. B. K., Bhatnagar-Mathur, P., Singam, P., Vadez, V., \& Sharma, K. K. (2020). An update and perspectives on the use of promoters in plant genetic engineering. Journal of Biosciences, 45(1), 119. http://dx.doi.org/10.1007/ s12038-020-00087-6. PMid:33097676.

Kyozuka, J., Fujimoto, H., Izawa, T., \& Shimamoto, K. (1991). Anaerobic induction and tissue-specific expression of maize Adh1 promoter in transgenic rice plants and their progeny. Molecular \& General Genetics, 228(1-2), 40-48. http://dx.doi.org/10.1007/ BF00282445. PMid:1715976.

Laxa, M. (2017). Intron-mediated enhancement: A tool for heterologous gene expression in plants? Frontiers in Plant Science, 7, 1977. http://dx.doi.org/10.3389/fpls.2016.01977. PMid:28111580.

Lee, S. C., Kim, D. S., Kim, N. H., \& Hwang, B. K. (2007). Functional analysis of the promoter of the pepper pathogen-induced gene, CAPIP2, during bacterial infection and abiotic stresses. Plant Science, 172(2), 236-245. http://dx.doi.org/10.1016/j. plantsci.2006.08.015.

Leitner-Dagan, Y., Ovadis, M., Shklarman, E., Elad, Y., Rav David, D., \& Vainstein, A. (2006). Expression and functional analyses of the plastid lipid-associated protein CHRC suggest its role in chromoplastogenesis and stress. Plant Physiology, 142(1), 233244. http://dx.doi.org/10.1104/pp.106.082404. PMid:16815957.

Li, H., Wang, Z., Han, K., Guo, M., Zou, Y., Zhang, W., Ma, W., \& Hua, H. (2020). Cloning and functional identification of a Chilo suppressalis-inducible promoter of rice gene, OsHPL2. Pest Management Science, 76(9), 3177-3187. http://dx.doi. org/10.1002/ps.5872. PMid:32336018.

Li, J., Xu, R.-F., Qin, R.-Y., Ma, H., Li, H., Zhang, Y.-P., Li, L., Wei, P. C., \& Yang, J. B. (2014). Isolation and functional characterization 
of a novel rice constitutive promoter. Plant Cell Reports, 33(10), 1651-1660. http://dx.doi.org/10.1007/s00299-014-1644-1. PMid:24980160.

Li, X., Gao, S., Tang, Y., Li, L., Zhang, F., Feng, B., Fang, Z., Ma, L., \& Zhao, C. (2015). Genome-wide identification and evolutionary analyses of bZIP transcription factors in wheat and its relatives and expression profiles of anther development related TabZIP genes. BMC Genomics, 16(1), 976. http://dx.doi.org/10.1186/ s12864-015-2196-7. PMid:26581444.

Liu, M., Shi, Z., Zhang, X., Wang, M., Zhang, L., Zheng, K., Liu, J., Hu, X., Di, C., Qian, Q., He, Z., \& Yang, D. L. (2019). Inducible overexpression of Ideal Plant Architecture 1 improves both yield and disease resistance in rice. Nature Plants, 5(4), 389-400. http://dx.doi.org/10.1038/s41477-019-0383-2. PMid:30886331.

Liu, W., Mazarei, M., Rudis, M. R., Fethe, M. H., \& Stewart Junior, C. N. (2011). Rapid in vivo analysis of synthetic promoters for plant pathogen phytosensing. BMC Biotechnology, 11(1), 108. http://dx.doi.org/10.1186/1472-6750-11-108. PMid:22093754.

Liu, W. , Yuan, J. S., \& Stewart Junior, C. N. (2013). Advanced genetic tools for plant biotechnology. Nature Reviews. Genetics, 14(11), 781-793. http://dx.doi.org/10.1038/nrg3583. PMid:24105275.

Livne, B., Faktor, O., Zeitoune, S., Edelbaum, O., \& Sela, I. (1997). TMV-induced expression of tobacco B-glucanase promoter activity is mediated by a single, inverted, GCC motif. Plant Science, 130(2), 159-169. http://dx.doi.org/10.1016/S0168-9452(97)00210-0.

Llorca, C. M., Potschin, M., \& Zentgraf, U. (2014). bZIPs and WRKYs: Two large transcription factor families executing two different functional strategies. Frontiers in Plant Science, 5, 169. http:// dx.doi.org/10.3389/fpls.2014.00169. PMid:24817872.

Loake, G. J., Faktor, O., Lamb, C. J., \& Dixon, R. A. (1992). Combination of H-box [CCTACC(N)7CT] and G-box (CACGTG) cis elements is necessary for feed-forward stimulation of a chalcone synthase promoter by the phenylpropanoid-pathway intermediate p-coumaric acid. Proceedings of the National Academy of Sciences of the United States of America, 89(19), 9230-9234. http:// dx.doi.org/10.1073/pnas.89.19.9230. PMid:1409628.

Lorberbaum, D. S., \& Barolo, S. (2015). Enhancers: holding out for the right promoter. Current Biology, 25(7), R290-R293. http:// dx.doi.org/10.1016/j.cub.2015.01.039. PMid:25829016.

Louder, R. K., He, Y., López-Blanco, J. R., Fang, J., Chacón, P., \& Nogales, E. (2016). Structure of promoter-bound TFIID and model of human pre-initiation complex assembly. Nature, 531(7596), 604609. http://dx.doi.org/10.1038/nature17394. PMid:27007846.

Lowder, L. G., Zhou, J., Zhang, Y., Malzahn, A., Zhong, Z., Hsieh, T.F., Voytas, D. F., Zhang, Y., \& Qi, Y. (2018). Robust transcriptional activation in plants using multiplexed CRISPR-Act2.0 and mTALEAct systems. Molecular Plant, 11(2), 245-256. http://dx.doi. org/10.1016/j.molp.2017.11.010. PMid:29197638.

Mac, A., Krzymowska, M., Barabasz, A., \& Hennig, J. (2004). Transcriptional regulation of the gluB promoter during plant response to infection. Cellular \& Molecular Biology Letters, 9(4B), 843-853. PMid:15647801.

Malnoy, M., Reynoird, J. P., Borejsza-Wysocka, E. E., \& Aldwinckle, H. S. (2006). Activation of the pathogen-inducible Gst1 promoter of potato after elicitation by Venturia inaequalis and Erwinia amylovora in transgenic apple (Malus $\mathrm{x}$ domestica). Transgenic Research, 15(1), 83-93. http://dx.doi.org/10.1007/s11248-0052943-7. PMid:16475012.

Malnoy, M., Venisse, J.-S., Reynoird, J. P., \& Chevreau, E. (2003). Activation of three pathogen-inducible promoters of tobacco in transgenic pear (Pyrus communis L.) after abiotic and biotic elicitation. Planta, 216(5), 802-814. http://dx.doi.org/10.1007/ s00425-002-0932-0. PMid:12624768.

Mann, D. G. J., King, Z. R., Liu, W., Joyce, B. L., Percifield, R. J., Hawkins, J. S., LaFayette, P. R., Artelt, B. J., Burris, J. N., Mazarei, M., Bennetzen, J. L., Parrott, W. A., \& Stewart Junior, C. N. (2011). Switchgrass (Panicum virgatum L.) polyubiquitin gene (PvUbi1 and PvUbi2) promoters for use in plant transformation.
BMC Biotechnology, 11(1), 74. http://dx.doi.org/10.1186/14726750-11-74. PMid:21745390.

Manners, J. M., Penninckx, I. A., Vermaere, K., Kazan, K., Brown, R. L., Morgan, A., Maclean, D. J., Curtis, M. D., Cammue, B. P., \& Broekaert, W. F. (1998). The promoter of the plant defensin gene PDF1.2 from Arabidopsis is systemically activated by fungal pathogens and responds to methyl jasmonate but not to salicylic acid. Plant Molecular Biology, 38(6), 1071-1080. http://dx.doi. org/10.1023/A:1006070413843. PMid:9869413.

Masura, S. S., Parveez, G. K. A., \& Ismail, I. (2010). Isolation and characterization of oil palm constitutive promoter derived from ubiquitin extension protein (uep1) gene. New Biotechnology, 27(4), 289-299. http://dx.doi.org/10.1016/j.nbt.2010.01.337. PMid:20123048.

Mauch-Mani, B., \& Slusarenko, A. J. (1996). Production of salicylic acid precursors is a major function of phenylalanine ammonia-lyase in the resistance of Arabidopsis to Peronospora parasitica. The Plant Cell, 8(2), 203-212. http://dx.doi.org/10.2307/3870265. PMid:12239383.

Mazarei, M., Teplova, I., Hajimorad, M. R., \& Stewart Junior, C. N. (2008). Pathogen phytosensing: Plants to report plant pathogens. Sensors (Basel), 8(4), 2628-2641. http://dx.doi.org/10.3390/ s8042628. PMid:27879840.

McElroy, D., Blowers, A. D., Jenes, B., \& Wu, R. (1991). Construction of expression vectors based on the rice actin 1 (Act1) 5 ' region for use in monocot transformation. Molecular \& General Genetics, 231(1), 150-160. http://dx.doi.org/10.1007/BF00293832. PMid:1753941.

McElroy, D., Zhang, W., Cao, J., \& Wu, R. (1990). Isolation of an efficient actin promoter for use in rice transformation. The Plant Cell, 2(2), 163-171. http://dx.doi.org/10.1105/tpc.2.2.163. PMid:2136633.

Mehrotra, R., \& Mehrotra, S. (2010). Promoter activation by ACGT in response to salicylic and abscisic acids is differentially regulated by the spacing between two copies of the motif. Journal of Plant Physiology, 167(14), 1214-1218. http://dx.doi.org/10.1016/j. jplph.2010.04.005. PMid:20554077.

Melo, B. P., Lourenço-Tessutti, I. T., Fraga, O. T., Pinheiro, L. B., De Jesus Lins, C. B., Morgante, C. V., Engler, J. A., Reis, P. A. B., Grossi-de-Sá, M. F., \& Fontes, E. P. B. (2021). Contrasting roles of GmNACO65 and GmNACO85 in natural senescence, plant development, multiple stresses and cell death responses. Scientific Reports, 11(1), 11178. http://dx.doi.org/10.1038/s41598-02190767-6. PMid:34045652.

Melo, B. P., Lourenço-Tessutti, I. T., Paixão, J. F. R., Noriega, D. D., Silva, M. C. M., Almeida-Engler, J., Fontes, E. P. B., \& Grosside-Sa, M. F. (2020). Transcriptional modulation of AREB-1 by CRISPRa improves plant physiological performance under severe water deficit. Scientific Reports, 10(1), 16231. http://dx.doi. org/10.1038/s41598-020-72464-y. PMid:33004844.

Mitchum, M. G., Sukno, S., Wang, X., Shani, Z., Tsabary, G., Shoseyov, O., \& Davis, E. L. (2004). The promoter of the Arabidopsis thaliana Cel1 endo-1,4-beta glucanase gene is differentially expressed in plant feeding cells induced by root-knot and cyst nematodes. Molecular Plant Pathology, 5(3), 175-181. http:// dx.doi.org/10.1111/j.1364-3703.2004.00216.x. PMid:20565607.

Mittler, R., \& Blumwald, E. (2010). Genetic engineering for modern agriculture: challenges and perspectives. Annual Review of Plant Biology, 61(1), 443-462. http://dx.doi.org/10.1146/annurevarplant-042809-112116. PMid:20192746.

Mohan, R., Bajar, A. M., \& Kolattukudy, P. E. (1993). Induction of a tomato anionic peroxidase gene (tap1) by wounding in transgenic tobacco and activation of tap1/GUS and tap2/GUS chimeric gene fusions in transgenic tobacco by wounding and pathogen attack. Plant Molecular Biology, 21(2), 341-354. http://dx.doi. org/10.1007/BF00019949. PMid:7678769.

Moran Lauter, A. N., Peiffer, G. A., Yin, T., Whitham, S. A., Cook, D., Shoemaker, R. C., \& Graham, M. A. (2014). Identification of candidate genes involved in early iron deficiency chlorosis signaling in soybean (Glycine max) roots and leaves. BMC 
Genomics, 15(1), 702. http://dx.doi.org/10.1186/1471-216415-702. PMid:25149281.

Moura, S. M., Freitas, E. O., Ribeiro, T. P., Paes-de-Melo, B., Arraes, F. B. M., Macedo, L. L. P., Paixão, J. F. R., Lourenço-Tessutti, I. T., Artico, S., Valença, D. C., Silva, M. C. M., Oliveira, A. C., Alves-Ferreira, M., \& Grossi-de-Sa, M. F. (2021). Discovery and functional characterization of novel cotton promoters with potential application to pest control. Plant Cell Reports, 11, 115.

Müller, F., \& Tora, L. (2014). Chromatin and DNA sequences in defining promoters for transcription initiation. Biochimica et Biophysica Acta, 1839(3), 118-128. http://dx.doi.org/10.1016/j. bbagrm.2013.11.003. PMid:24275614.

Nakashima, K., Tran, L.-S. P., Van Nguyen, D., Fujita, M., Maruyama, K., Todaka, D., Ito, Y., Hayashi, N., Shinozaki, K., \& Yamaguchi-Shinozaki, K. (2007). Functional analysis of a NACtype transcription factor OsNAC6 involved in abiotic and biotic stress-responsive gene expression in rice. The Plant Journal, 51(4), 617-630. http://dx.doi.org/10.1111/j.1365-313X.2007.03168.x. PMid:17587305.

Ni, M., Cui, D., Einstein, J., Narasimhulu, S., Vergara, C. E., \& Gelvin, S. B. (1995). Strength and tissue specificity of chimeric promoters derived from the octopine and mannopine synthase genes. The Plant Journal, 7(4), 661-676. http://dx.doi.org/10.1046/j.1365313X.1995.7040661.x.

Nishiuchi, T., Shinshi, H., \& Suzuki, K. (2004). Rapid and transient activation of transcription of the ERF3 gene by wounding in tobacco leaves: Possible involvement of NtWRKYs and autorepression. The Journal of Biological Chemistry, 279(53), 55355-55361. http:// dx.doi.org/10.1074/jbc.M409674200. PMid:15509567.

Obertello, M., Santi, C., Sy, M.-O., Laplaze, L., Auguy, F., Bogusz, D., \& Franche, C. (2005). Comparison of four constitutive promoters for the expression of transgenes in the tropical nitrogen-fixing tree Allocasuarina verticillata. Plant Cell Reports, 24(9), 540-548. http://dx.doi.org/10.1007/s00299-005-0963-7. PMid:15940528.

Pan, Y., Chen, R., Zhu, L., Wang, H., Huang, D., \& Lang, Z. (2016). Utilizing modified ubi1 introns to enhance exogenous gene expression in maize (Zea mays L.) and rice (Oryza sativa L.). Journal of Integrative Agriculture, 15(8), 1716-1726. http:// dx.doi.org/10.1016/S2095-3119(15)61260-6.

Pandey, S. P., Singh, A. P., Srivastava, S., Chandrashekar, K., \& Sane, A. P. (2019). A strong early acting wound-inducible promoter, $R b P C D 1 p r o$, activates crylAc expression within minutes of wounding to impart efficient protection against insects. Plant Biotechnology Journal, 17(7), 1458-1470. http://dx.doi.org/10.1111/pbi.13071. PMid:30623549.

Park, H. C., Kim, M. L., Kang, Y. H., Jeon, J. M., Yoo, J. H., Kim, M. C., Park, C. Y., Jeong, J. C., Moon, B. C., Lee, J. H., Yoon, H. W., Lee, S. H., Chung, W. S., Lim, C. O., Lee, S. Y., Hong, J. C., \& Cho, M. J. (2004). Pathogen- and NaCl-induced expression of the SCaM-4 promoter is mediated in part by a GT-1 box that interacts with a GT-1-like transcription factor. Plant Physiology, 135(4), 2150-2161. http://dx.doi.org/10.1104/pp.104.041442. PMid:15310827.

Park, H. C., Kim, M. L., Kang, Y. H., Jeong, J. C., Cheong, M. S., Choi, W., Lee, S. Y., Cho, M. J., Kim, M. C., Chung, W. S., \& Yun, D. J. (2009). Functional analysis of the stress-inducible soybean calmodulin isoform-4 ( $\mathrm{GmCaM}-4)$ promoter in transgenic tobacco plants. Molecules and Cells, 27(4), 475-480. http://dx.doi. org/10.1007/s10059-009-0063-6. PMid:19390829.

Park, S.-H., Bang, S. W., Jeong, J. S., Jung, H., Redillas, M. C. F. R., Kim, H. I., Lee, K. H., Kim, Y. S., \& Kim, J. K. (2012). Analysis of the $A P X, P G D 1$ and $R 1 G 1 B$ constitutive gene promoters in various organs over three homozygous generations of transgenic rice plants. Planta, 235(6), 1397-1408. http://dx.doi.org/10.1007/ s00425-011-1582-x. PMid:22212906.

Perera, M. R., \& Jones, M. G. K. (2004). Expression of the peroxidase gene promoter (Shpx6b) from Stylosanthes humilis in transgenic plants during insect attack. Entomologia Experimentalis et
Applicata, 111(3), 165-171. http://dx.doi.org/10.1111/j.00138703.2004.00170.x.

Petolino, J. F., \& Davies, J. P. (2013). Designed transcriptional regulators for trait development. Plant Science, 201-202, 128-136. http://dx.doi.org/10.1016/j.plantsci.2012.12.006. PMid:23352411.

Plesch, G., Ehrhardt, T., \& Mueller-Roeber, B. (2001). Involvement of TAAAG elements suggests a role for Dof transcription factors in guard cell-specific gene expression. The Plant Journal, 28(4), 455-464. http://dx.doi.org/10.1046/j.1365-313X.2001.01166.x. PMid:11737782.

Porto, M. S., Pinheiro, M. P. N., Batista, V. G. L., Santos, R. C., Melo Filho, P., \& Lima, L. M. (2014). Plant promoters: An approach of structure and function. Molecular Biotechnology, 56(1), 38-49. http://dx.doi.org/10.1007/s12033-013-9713-1. PMid:24122284.

Puzio, P. S., Lausen, J., Heinen, P., \& Grundler, F. M. (2000). Promoter analysis of pyk20, a gene from Arabidopsis thaliana. Plant Science, 157(2), 245-255. http://dx.doi.org/10.1016/ S0168-9452(00)00287-9. PMid:10960738.

Quilis, J., López-García, B., Meynard, D., Guiderdoni, E., \& San Segundo, B. (2014). Inducible expression of a fusion gene encoding two proteinase inhibitors leads to insect and pathogen resistance in transgenic rice. Plant Biotechnology Journal, 12(3), 367-377. http://dx.doi.org/10.1111/pbi.12143. PMid:24237606.

Ranjan, A., Westrick, N. M., Jain, S., Piotrowski, J. S., Ranjan, M., Kessens, R., Stiegman, L., Grau, C. R., Conley, S. P., Smith, D. L., \& Kabbage, M. (2019). Resistance against Sclerotinia sclerotiorum in soybean involves a reprogramming of the phenylpropanoid pathway and up-regulation of antifungal activity targeting ergosterol biosynthesis. Plant Biotechnology Journal, 17(8), 15671581. http://dx.doi.org/10.1111/pbi.13082. PMid:30672092.

Rasco-Gaunt, S., Liu, D., Li, C. P., Doherty, A., Hagemann, K., Riley, A., Thompson, T., Brunkan, C., Mitchell, M., Lowe, K., Krebbers, E., Lazzeri, P., Jayne, S., \& Rice, D. (2003). Characterization of the expression of a novel constitutive maize promoter in transgenic wheat and maize. Plant Cell Reports, 21(6), 569-576. http://dx.doi.org/10.1007/s00299-002-0552-y. PMid:12789432.

Ren, Z., Liu, J., Din, G. M. U., Zhang, H., Du, Z., Chen, W., Liu, T., Zhang, J., Zhao, S., \& Gao, L. (2020). Transcriptome analysis of wheat spikes in response to Tilletia controversa Kühn which cause wheat dwarf bunt. Scientific Reports, 10(1), 21567. http://dx.doi. org/10.1038/s41598-020-78628-0. PMid:33299089.

Ribeiro, T. P., Lourenço-Tessutti, I. T., de Melo, B. P., Morgante, C. V., Filho, A. S., Lins, C. B. J., Ferreira, G. F., Mello, G. N., Macedo, L. L. P., Lucena, W. A., Silva, M. C. M., Oliveira-Neto, O. B. , \& Grossi-de-Sa, M. F. (2021). Improved cotton transformation protocol mediated by Agrobacterium and biolistic combinedmethods. Planta, 254(2), 20. http://dx.doi.org/10.1007/s00425021-03666-5. PMid:34216275.

Roca Paixão, J. F., Gillet, F.-X., Ribeiro, T. P., Bournaud, C., Lourenço-Tessutti, I. T., Noriega, D. D., Melo, B. P., de AlmeidaEngler, J., \& Grossi-de-Sa, M. F. (2019). Improved drought stress tolerance in Arabidopsis by CRISPR/dCas9 fusion with a Histone AcetylTransferase. Scientific Reports, 9(1), 8080. http://dx.doi. org/10.1038/s41598-019-44571-y. PMid:31147630.

Rogers, H. J., Bate, N., Combe, J., Sullivan, J., Sweetman, J., Swan, C., Lonsdale, D. M., \& Twell, D. (2001). Functional analysis of cis-regulatory elements within the promoter of the tobacco late pollen gene g10. Plant Molecular Biology, 45(5), 577-585. http://dx.doi.org/10.1023/A:1010695226241. PMid:11414616.

Römer, P., Recht, S., \& Lahaye, T. (2009). A single plant resistance gene promoter engineered to recognize multiple TAL effectors from disparate pathogens. Proceedings of the National Academy of Sciences of the United States of America, 106(48), 20526-20531. http://dx.doi.org/10.1073/pnas.0908812106. PMid:19910532.

Ross, E. J. H., Stone, J. M., Elowsky, C. G., Arredondo-Peter, R., Klucas, R. V., \& Sarath, G. (2004). Activation of the Oryza sativa non-symbiotic haemoglobin-2 promoter by the cytokinin-regulated transcription factor, ARR1. Journal of Experimental Botany, 
55(403), 1721-1731. http://dx.doi.org/10.1093/jxb/erh211. PMid:15258171.

Rushton, P. J., Reinstädler, A., Lipka, V., Lippok, B., \& Somssich, I. E. (2002). Synthetic plant promoters containing defined regulatory elements provide novel insights into pathogen- and wound-induced signaling. The Plant Cell, 14(4), 749-762. http: // dx.doi.org/10.1105/tpc.010412. PMid:11971132.

Sakai, H., Aoyama, T., \& Oka, A. (2000). Arabidopsis ARR1 and ARR2 response regulators operate as transcriptional activators. The Plant Journal, 24(6), 703-711. http:/ / dx.doi.org/10.1046/j.1365313x.2000.00909.x. PMid:11135105.

Saxonov, S., Berg, P. \& Brutlag, D. L. (2006). A genome-wide analysis of $\mathrm{CPG}$ dinucleotides in the human genome distinguishes two distinct classes of promoters. Proceedings of the National Academy of Sciences of the United States of America, 103(5), 1412-1417. http://dx.doi.org/10.1073/pnas.0510310103. PMid:16432200.

Schiek, B., Hareau, G., Baguma, Y., Medakker, A., Douches, D., Shotkoski, F., \& Ghislain, M. (2016). Demystification of GM crop costs: Releasing late blight resistant potato varieties as public goods in developing countries. International Journal of Biotechnology, 14(2), 112. http://dx.doi.org/10.1504/ IJBT.2016.077942.

Sheshadri, S. A., Nishanth, M. J., \& Simon, B. (2016). Stress-mediated cis-element transcription factor interactions interconnecting primary and specialized metabolism in planta. Frontiers in Plant Science, 7, 1725. http://dx.doi.org/10.3389/fpls.2016.01725. PMid:27933071.

Shirasawa-Seo, N., Mitsuhara, I., Nakamura, S., Murakami, T., Iwai, T., Nishizawa, Y., Hibi, T., \& Ohashi, Y. (2002). Constitutive promoters available for transgene expression instead of caMV 35S RNA promoter: Arabidopsis promoters of tryptophan synthase protein B subunit and phytochrome B. Plant Biotechnology (Sheffield, England), 19(1), 19-26. http://dx.doi.org/10.5511/ plantbiotechnology.19.19.

Shokouhifar, F., Zamani, M. R., Motallebi, M., Mousavi, A., \& Malboobi, M. A. (2011). Construction and functional analysis of pathogen-inducible synthetic promoters in Brassica napus. Biologia Plantarum, 55(4), 689-695. http://dx.doi.org/10.1007/ s10535-011-0169-5.

Shukla, N., Yadav, R., Kaur, P., Rasmussen, S., Goel, S., Agarwal, M., Jagannath, A., Gupta, R., \& Kumar, A. (2018). Transcriptome analysis of root-knot nematode (Meloidogyne incognita)-infected tomato (Solanum lycopersicum) roots reveals complex gene expression profiles and metabolic networks of both host and nematode during susceptible and resistance responses. Molecular Plant Pathology, 19(3), 615-633. http://dx.doi.org/10.1111/ mpp.12547. PMid:28220591.

Singhal, P., Jan, A. T., Azam, M., \& Haq, Q. M. R. (2016). Plant abiotic stress: A prospective strategy of exploiting promoters as alternative to overcome the escalating burden. Frontiers in Life Science, 9(1), 52-63. http://dx.doi.org/10.1080/21553769 .2015.1077478.

Song, M.-A., Tiirikainen, M., Kwee, S., Okimoto, G., Yu, H., \& Wong, L. L. (2013). Elucidating the landscape of aberrant DNA methylation in hepatocellular carcinoma. PLoS One, 8(2), e55761. http:// dx.doi.org/10.1371/journal.pone.0055761. PMid:23437062.

Spitz, F., \& Furlong, E. E. M. (2012). Transcription factors: from enhancer binding to developmental control. Nature Reviews. Genetics, 13(9), 613-626. http://dx.doi.org/10.1038/nrg3207. PMid:22868264.

Stålberg, K., Ellerstöm, M., Ezcurra, I., Ablov, S., \& Rask, L. (1996). Disruption of an overlapping E-box/ABRE motif abolished high transcription of the napA storage-protein promoter in transgenic Brassica napus seeds. Planta, 199(4), 515-519. http://dx.doi. org/10.1007/BF00195181. PMid:8818291.

Strompen, G., Grüner, R., \& Pfitzner, U. M. (1998). An as-1-like motif controls the level of expression of the gene for the pathogenesisrelated protein 1a from tobacco. Plant Molecular Biology,
37(5), 871-883. http://dx.doi.org/10.1023/A:1006003916284. PMid:9678582.

Sukno, S., Shimerling, O., McCuiston, J., Tsabary, G., Shani, Z., Shoseyov, O., \& Davis, E. L. (2006). expression and regulation of the Arabidopsis thaliana cel1 endo 1,4 beta glucanase gene during compatible plant-nematode interactions. Journal of Nematology, 38(3), 354-361. PMid:19259541.

Sun, B., Sun, G., Meng, Z., Zhang, R., \& Guo, S. (2016). A novel constitutive promoter and its downstream 5 ' UTR derived from cotton (Gossypium spp.) drive high-level gene expression in stem and leaf tissues. Journal of Integrative Agriculture, 15(4), 755-762. http://dx.doi.org/10.1016/S2095-3119(15)61054-1.

Sun, C., Palmqvist, S., Olsson, H., Borén, M., Ahlandsberg, S., \& Jansson, C. (2003). A novel WRKY transcription factor, SUSIBA2, participates in sugar signaling in barley by binding to the sugar-responsive elements of the iso 1 promoter. The Plant Cell, 15(9), 2076-2092. http://dx.doi.org/10.1105/tpc.014597. PMid:12953112.

Sunilkumar, G., Connell, J. P., Smith, C. W., Reddy, A. S., \& Rathore, K. S. (2002). Cotton alpha-globulin promoter: Isolation and functional characterization in transgenic cotton, Arabidopsis, and tobacco. Transgenic Research, 11(4), 347-359. http://dx.doi. org/10.1023/A:1016322428517. PMid:12212838.

Swartzberg, D., Kirshner, B., Rav-David, D., Elad, Y., \& Granot, D. (2008). Botrytis cinerea induces senescence and is inhibited by autoregulated expression of the IPT gene. European Journal of Plant Pathology, 120(3), 289-297. http://dx.doi.org/10.1007/ s10658-007-9217-6.

Tao, Y. B., He, L. L., Niu, L. J., \& Xu, Z. F. (2015). Isolation and characterization of an ubiquitin extension protein gene (JCUEP) promoter from Jatropha curcas. Planta, 241(4), 823-836. http: / / dx.doi.org/10.1007/s00425-014-2222-z. PMid:25502690.

Terzaghi, W. B., \& Cashmore, A. R. (1995). Light-regulated transcription. Annual Review of Plant Physiology and Plant Molecular Biology, 46(1), 445-474. http://dx.doi.org/10.1146/ annurev.pp.46.060195.002305.

Thurau, T., Kifle, S., Jung, C., \& Cai, D. (2003). The promoter of the nematode resistance gene Hs1pro-1 activates a nematode-responsive and feeding site-specific gene expression in sugar beet (Beta vulgaris L.) and Arabidopsis thaliana. Plant Molecular Biology, 52(3), 643-660. http://dx.doi. org/10.1023/A:1024887516581. PMid:12956533.

Toquin, V., Grausem, B., Geoffroy, P., \& Legrand, M. (2003). Structure of the tobacco caffeic acid O-methyltransferase (COMT) II gene: Identification of promoter sequences involved in gene inducibility by various stimuli. Plant Molecular Biology, 52(3), 495-509. http://dx.doi.org/10.1023/A:1024810916909. PMid:12956522.

Tripathi, S. A., Olson, D. G., Argyros, D. A., Miller, B. B., Barrett, T. F., Murphy, D. M., McCool, J. D., Warner, A. K., Rajgarhia, V. B., Lynd, L. R., Hogsett, D. A., \& Caiazza, N. C. (2010). Development of pyrF-based genetic system for targeted gene deletion in Clostridium thermocellum and creation of a pta mutant. Applied and Environmental Microbiology, 76(19), 6591-6599. http:// dx.doi.org/10.1128/AEM.01484-10. PMid:20693441.

Vernimmen, D., \& Bickmore, W. A. (2015). The hierarchy of transcriptional activation: from enhancer to promoter. Trends in Genetics, 31(12), 696-708. http://dx.doi.org/10.1016/j. tig.2015.10.004. PMid:26599498.

Viana, A. A., Fragoso, R. R., Guimarães, L. M., Pontes, N., OliveiraNeto, O. B., Artico, S., Nardeli, S. M., Alves-Ferreira, M., Batista, J. A., Silva, M. C., \& Grossi-de-Sa, M. F. (2011). Isolation and functional characterization of a cotton ubiquitination-related promoter and 5'UTR that drives high levels of expression in root and flower tissues. BMC Biotechnology, 11(1), 115. http://dx.doi. org/10.1186/1472-6750-11-115. PMid:22115195.

Viana, V. E. , Carlos da Maia, L., Busanello, C., Pegoraro, C. \& Costa de Oliveira, A. (2021). When rice gets the chills: Comparative transcriptome profiling at germination shows WRKY transcription 
factor responses. Plant biology, 23(Suppl. 1), 100-112. http:// dx.doi.org/10.1111/plb.13262. PMid:33773005.

Vijayan, J., Devanna, B. N., Singh, N. K., \& Sharma, T. R. (2015). Cloning and functional validation of early inducible Magnaporthe oryzae responsive CYP76M7 promoter from rice. Frontiers in Plant Science, 6, 371. http://dx.doi.org/10.3389/fpls.2015.00371. PMid:26052337.

Wang, J., \& Oard, J. H. (2003). Rice ubiquitin promoters: Deletion analysis and potential usefulness in plant transformation systems. Plant Cell Reports, 22(2), 129-134. http://dx.doi.org/10.1007/ s00299-003-0657-y. PMid:12827439.

Wang, R., Zhu, M., Ye, R., Liu, Z., Zhou, F., Chen, H., \& Lin, Y. (2015). Novel green tissue-specific synthetic promoters and cis-regulatory elements in rice. Scientific Reports, 5(1), 18256. http://dx.doi. org/10.1038/srep18256. PMid:26655679.

Wang, X., Lu, J., Chen, H., Shan, Z., Shen, X., Duan, B., Zhang, C., Yang, Z., Zhang, X., Qiu, D., Chen, S., Zhou, X., \& Jiao, Y. (2017). Comparative analyses of transcriptome and proteome in response to cotton bollworm between a resistant wild soybean and a susceptible soybean cultivar. Plant Cell, Tissue and Organ Culture, 129(3), 511-520. http://dx.doi.org/10.1007/s11240017-1196-5.

Wang, X., Replogle, A., Davis, E. L., \& Mitchum, M. G. (2007). The tobacco Cel7 gene promoter is auxin-responsive and locally induced in nematode feeding sites of heterologous plants. Molecular Plant Pathology, 8(4), 423-436. http://dx.doi.org/10.1111/j.13643703.2007.00403.x. PMid:20507511.

Wei, K., Chen, J., Wang, Y., Chen, Y., Chen, S., Lin, Y., Pan, S., Zhong, X., \& Xie, D. (2012). Genome-wide analysis of bZIP-encoding genes in maize. DNA Research, 19(6), 463-476. http://dx.doi. org/10.1093/dnares/dss026. PMid:23103471.

Wilmink, A., van de Ven, B. C., \& Dons, J. J. (1995). Activity of constitutive promoters in various species from the Liliaceae. Plant Molecular Biology, 28(5), 949-955. http://dx.doi.org/10.1007/ BF00042079. PMid:7640366.

Wiśniewska, A., Dąbrowska-Bronk, J., Szafrański, K., Fudali, S., Święcicka, M., Czarny, M., Wilkowska, A., Morgiewicz, K., Matusiak, J., Sobczak, M., \& Filipecki, M. (2013). Analysis of tomato gene promoters activated in syncytia induced in tomato and potato hairy roots by Globodera rostochiensis. Transgenic Research, 22(3), 557-569. http://dx.doi.org/10.1007/s11248-012-9665-4. PMid:23129482.

Xiao, K., Zhang, C., Harrison, M., \& Wang, Z.-Y. (2005). Isolation and characterization of a novel plant promoter that directs strong constitutive expression of transgenes in plants. Molecular Breeding, 15(2), 221-231. http://dx.doi.org/10.1007/s11032004-5679-9.

Xie, M., He, Y., \& Gan, S. (2001). Bidirectionalization of polar promoters in plants. Nature Biotechnology, 19(7), 677-679. http://dx.doi.org/10.1038/90296. PMid:11433282.

Yamada, Y., \& Sato, F. (2013). Transcription factors in alkaloid biosynthesis. International Review of Cell and Molecular Biology,
305, 339-382. http://dx.doi.org/10.1016/B978-0-12-4076952.00008-1. PMid:23890386.

Yamaguchi-Shinozaki, K., \& Shinozaki, K. (2005). Organization of cisacting regulatory elements in osmotic- and cold-stress-responsive promoters. Trends in Plant Science, 10(2), 88-94. http://dx.doi. org/10.1016/j.tplants.2004.12.012. PMid:15708346.

Yanagisawa, S. (2000). Dof1 and Dof2 transcription factors are associated with expression of multiple genes involved in carbon metabolism in maize. The Plant Journal, 21(3), 281-288. http: // dx.doi.org/10.1046/j.1365-313x.2000.00685.x. PMid:10758479.

Yang, F., Ding, X., Chen, J., Shen, Y., Kong, L., Li, N., \& Chu, Z. (2017a). Functional analysis of the GRMZM2G174449 promoter to identify Rhizoctonia solani-inducible cis-elements in maize. BMC Plant Biology, 17(1), 233. http://dx.doi.org/10.1186/s12870017-1181-5. PMid:29202693.

Yang, Y., Zhou, Y., Chi, Y., Fan, B., \& Chen, Z. (2017b). Characterization of soybean WRKY gene family and identification of soybean wrky genes that promote resistance to soybean cyst nematode. Scientific Reports, 7(1), 17804. http://dx.doi.org/10.1038/ s41598-017-18235-8. PMid:29259331.

Yaqoob, A., Ali Shahid, A., Salisu, I. B., Shakoor, S., Usmaan, M., Shad, M., \& Rao, A. Q. (2020). Comparative analysis of Constitutive and fiber-specific promoters under the expression pattern of Expansin gene in transgenic Cotton. PLoS One, 15(3), e0230519. http:// dx.doi.org/10.1371/journal. pone.0230519. PMid:32187234.

Yevtushenko, D. P., Sidorov, V. A., Romero, R., Kay, W. W., \& Misra, S. (2004). Wound-inducible promoter from poplar is responsive to fungal infection in transgenic potato. Plant Science, 167(4), 715-724. http://dx.doi.org/10.1016/j.plantsci.2004.04.023.

Yu, D., Chen, C., \& Chen, Z. (2001). Evidence for an important role of WRKY DNA binding proteins in the regulation of NPR1 gene expression. The Plant Cell, 13(7), 1527-1540. http://dx.doi. org/10.1105/TPC.010115. PMid:11449049.

Zeng, W., Sun, Z., Cai, Z., Chen, H., Lai, Z., Yang, S., \& Tang, X. (2017). Comparative transcriptome analysis of soybean response to bean pyralid larvae. BMC Genomics, 18(1), 871. http://dx.doi. org/10.1186/s12864-017-4256-7. PMid:29132375.

Zhang, N., McHale, L. K., \& Finer, J. J. (2019). Changes to the core and flanking sequences of G-box elements lead to increases and decreases in gene expression in both native and synthetic soybean promoters. Plant Biotechnology Journal, 17(4), 724-735. http:// dx.doi.org/10.1111/pbi.13010. PMid:30191675.

Zhang, Z. L., Xie, Z., Zou, X., Casaretto, J., Ho, T. H., \& Shen, Q. J. (2004). A rice WRKY gene encodes a transcriptional repressor of the gibberellin signaling pathway in aleurone cells. Plant Physiology, 134(4), 1500-1513. http://dx.doi.org/10.1104/ pp.103.034967. PMid:15047897.

Zhu, B., Chen, T. H., \& Li, P. H. (1995). Activation of two osmotin-like protein genes by abiotic stimuli and fungal pathogen in transgenic potato plants. Plant Physiology, 108(3), 929-937. http://dx.doi. org/10.1104/pp.108.3.929. PMid:7630973. 


\section{Supplementary Material}

Supplementary material accompanies this paper.

Supplementary Table S1. Dataset of soybean biotic stress-related genes. The 50 soybean genes were selected from 06 transcriptomes of several biotic stresses, including a virus, a phytonematode, different caterpillars, and fungi.

Supplementary Table S2. Search strategy and total patent entries for constitutive plant promoters and regulated promoters in plants induced by biotic stress in WIPO PatentScope database.

Supplementary Table S3. Soybean and Cotton promoters and transgenes in commercial plants.

This material is available as part of the online article from http://www.biori.periodikos.com.br/current 